\title{
Innovation intensity of military-connected firms
}

\author{
Iman Harymawan, Fajar Kristanto Gautama Putra, Amalia Rizki and \\ Mohammad Nasih \\ Accountancy, Universitas Airlangga, Surabaya, Indonesia
}

\begin{abstract}
Purpose - The study aims to examine the military-connected firms' risk preference, specifically in the innovation intensity level context. The authors argue that firms with military-experienced top management have conservative and risk-averse behavior, influencing the innovation investment policy.

Design/methodology/approach - The authors use nonfinancial Indonesian-listed firms from 2010 to 2018 amounted to 2,504 firm-year observations.

Findings - The authors document a negative relationship between military connection with both innovation activities and outputs. The additional analysis documents that risk-preferences of military-connected firms will be drastically changed when the industry has a high digital level, which confirms that risk-averse militaryexperienced management is less dominant with adaptation skill. The authors also identify that veterans did not need a long tenure to influence firms' innovation investment policy. Lastly, the result is robust due to various endogeneity tests employed.
\end{abstract}

Originality/value - This study further examines military-connected firms' technological innovation compared to prior studies and enriches the related literature.

Keywords Military connection, Innovation intensity, Research and development, Intangibles

Paper type Research paper

\section{Introduction}

What the military is really good at doing is teaching you to plan and program... The essence of being an officer is to figure out how to deploy forces and resources to get something done. From a management standpoint, that is one of the really great lessons. -Michael Jordan, CEO Electronic Data Systems-

Military connection in business studies is rapidly growing recently, despite the number of military CEOs decreasing (Benmelech and Frydman, 2015). A growing literature shows military leaders are perceived to have potential traits favorable for business development. Recently, Kellog Insight (2019) published their interview with military leaders and business experts, highlighting that qualities of a well-run business are described at their best, as like the US military. The values, commitment and integrity of a military career should be woven into mission statements and corporate mantras (Citroën, 2018).

Another study shows dissimilarities, which points out the possibility of military personnel's several drawbacks as business management. Psychology studies imply that military personnel lack of ability to feel emotion, such as being like robots who can act but not feel (Gray and Wegner, 2011, 2012). In addition, based on dyadic morality theory (DMT), people's perception regarding military personnel is dominated by positive thoughts and as heroes (Schein and Gray, 2018), which may minimize the awareness of military personnel's inability to feel emotions and sensations (Shepherd et al., 2019). Moreover, veterans are not familiar with innovation and delivering results, which are business core values, during their military career (SHRM Foundation and NAVSO, 2017). Thus, it is debatable related to selecting military personnel as it is possible to provide different advantages or disadvantages if selecting them as one of the top management team.

This study is funded by the Simlitabmas Penelitian Dasar 2018 research scheme. The authors also thank Prof. Alfred Yawson and the unknown reviewer for managing the manuscript.
Innovation intensity

Received 11 December 2020 Revised 12 April 2021 28 April 2021 Accepted 28 May 2021

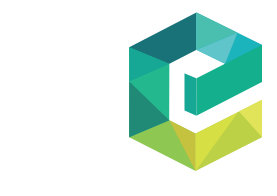

International Journal of Managerial Finance $1743-9132$ $1743-9132$
$2-2020-0616$ 
One of military connection's recent study is examining military-experienced boards' risk preference, specifically for firm's innovation intensity (Guo et al., 2020). They argue that military personnel has risk-averse characteristics, and if they are positioned as firm's top management, they will dominate the corporate decision-making process (Nasih et al., 2019), including the firm's innovation intensity policies. The hypothetical relationship follows the upper-echelon theory, which states that corporate action reflects its top management's traits (Hambrick, 2007). This study is inspired by Guo et al. (2020) and examines the relationship of military-connected firms with innovation intensity. We conjecture that there is a negative relationship between militaryconnected firms with innovation intensity, as proposed by Guo et al. (2020).

We posit several differences compared to Guo et al.'s (2020) study. First, our innovation intensity measurement is differentiated into two categories, namely innovation process and innovation output (Xue, 2007). We argue that this differentiation is crucial as not all research and development (RND) activities successfully generate innovation output such as patents. This differentiation also plays a crucial role as innovation can be internally generated or purchased from external parties. It is hoped that, based on this categorization of innovation intensity, we can further explore what is the prioritization of military-connected firms in terms of the relationship between innovation process or output.

Inspired by Benmelech and Frydman (2015), who consider the external environment of the military-connected firms, we employ firm's industry-level based on the taxonomy of digital intensive sectors (Calvino et al., 2018) developed by OECD. Our second difference comes from our opinion that military personnel might change risk preference based on digital industry levels. This argument is constructed as, during their military career, military personnel adapt to situations and conditions and make strategies based on them. Therefore, different industry digital levels require different innovation intensity policies of military-connected firms.

The third difference is also related to measurement, but we focus on the military connection aspect. We are not solely examining the existence of a military connection but also its position in organizational structure, military affiliation and recent military-experienced top management promotion (Nasih et al., 2019). We employ these additional military connection measurements as there is the possibility of differences in military personnel's risk profile and influence in corporations if they have different positions, affiliations and promotions.

This study used Indonesian-listed firms with the exclusion of SIC 6 from the period 2010 to 2018, which amounted to 2,504 firm-year observations as the final sample. We use ordinary least squares regression with the cluster approach (Petersen, 2009) to test our research hypothesis. We also employ Coarsened Exact Matching (CEM), Heckman two-stage regression and change analysis regression to address the endogeneity issue, precisely the self-selection bias concern.

We identified $22 \%$ of our sample as military-connected firms that contradict Benmelech and Frydman (2015), who claim military-connected firms in the US show diminishing trends. We found a negative relationship between military connection with innovation intensity, both in innovation process and output. This negative relationship is also robust as it shows consistent results across endogeneity tests. Our additional analysis shows that, regardless of the digital industry level, the relationship test result is consistent, except for the high digital level of the industry sample. We also document a consistent result of the relationship between military connection with innovation intensity in all types of military connection that we identify in this study. Finally, we also document that a recent appointed military-experienced management already substantially influences the firm in minimizing innovation activities.

This study makes several crucial contributions. First, it provides additional evidence on the upper-echelon theory, particularly a military-experienced top management. Their former career leads the military-connected firms to impose a similar policy, including lowering the innovation intensity. Second, our study employs several innovation intensity proxies and military connection types. Our result finds that regardless of the proxies and types, 
the negative relationship between military connection and innovation intensity is consistent. Third, we contemplate the industry's digital level as an external environment related to the relationship. We document a surprising result where military-connected firms in high industry digital level have tendencies to enhance their innovation intensity as their remarkable adaption competencies. Fourth, unlike other managers, military-experienced management does not need a long tenure to influence the firm's policy. Finally, our results provide several important insights for stakeholders, investors and top management teams who seek to understand the incentives and disincentives of positioning a militaryexperienced individual as one of the top management teams.

The remainder of this paper is organized as follows. "Literature Review" reviews the relevant literature and develops our hypotheses. "Research Design" describes the research design employed by this study. We report our results into three sections, namely "Main Results", "Robustness Tests" and "Additional Analysis". Finally, "Conclusion" concludes the paper and provides future recommendations.

\section{Literature review}

Military persona in business

Veterans have been acknowledged an untapped pool of talent for business. Based on the US Bureau of Labor Statistics, only 3.1\% of US veterans were not hired after their military career in 2019 compared to $3.6 \%$ of the total unemployment rate (US Bureau of Labor Statistics, 2020). This result supports a survey in 2016, which found approximately $37 \%$ of 2,500 hiring managers are interested and commit to hiring military veterans (CareerBuilder, 2016). Among 26 top worldwide companies, 21 of them had formal veteran programs and total hiring for veterans for around 200,000 at the end of 2014 (Rand Corporation, 2014) [1]. Although Benmelech and Frydman (2015) show diminishing trends of veterans seated as CEOs to $6.2 \%$, a statistical report on the military retirement systems shows that, in aggregate, veterans contribute a significant portion on boards. In the US alone, roughly 245,000 retired senior military officers are employed as top management teams (Defence.gov., 2015). These numbers explicitly show that military-experienced individuals have become lead candidate priorities in the hiring process by employers. These numbers prove that service in the military is a life-altering experience (MacLean and Elder, 2007; Spiro and Settersten, 2012), making them unique compared to those who do not serve.

There are rationales for employing veterans as one of the business priorities. Veterans are overwhelmingly perceived positively and as all-around heroes who can plan, take action and get things done (Shepherd et al., 2019). What comes to people's mind is that a militaryexperienced person is an individual that has a strong will, yet is very adaptive so can manage tactics to ensure that the goal is achieved. They are also known for their integrity, initiatives and courage as military core values synchronized with business practices in general (SHRM Foundation and NAVSO, 2017). These values are habituated by military personnel as their daily training consistently emphasizes them (Duffy, 2006; Jones, 2005). Overall, what military members learn during their careers is suitable for current business needs.

Conversely, there is also a contra of choosing veterans as corporate leaders from a moral judgment standpoint. Although a military job description closely ties with protecting and provide assistance for civilians, psychological studies posit a different perspective. In other words, military personnel's morality is based on specific instructions, and we cannot ignore the fact that some of their "dirty works" tend to contradict their "vulnerable feelers" personality. Therefore, the possibilities that military personnel, including veterans, are less vulnerable to feel sensations and emotions are pretty high (Shepherd et al., 2019). This inability to experience emotions is problematic if a business leader has to make a moral 
judgment as Gray and Wegner $(2011,2012)$ imply that they are more like a robot, an individual that can do anything (agency), but not feel it (experience).

These two opposing perspectives make for an undecided issue regarding employing military personnel as part of business, especially when they are positioned as business leaders. An increasing number of studies have tried to solve this contentious issue. This study tries to expand the scope of this issue by looking at different military personnel traits that have not yet been examined comprehensively. This study focuses on the military personnel's risk preference and core values related to the business decision-making process.

Military leaders often make dozens of consequential judgments over a day and, from those processes, most involve attitudes toward risk. Surprisingly, Bell et al. (2018) found that military cadets have a risk aversion pattern compared to others, despite their jobs being directly linked to "risk". Ault (2003) argues that this risk-averse trait is driven by the centralized decision-making structure of the military. There are two possibilities of riskaverse behavior developed in military personnel related to their professional activities. The first is stress management capability, and the second is their in-depth analysis habit. Facing uncertainties is common for military personnel, and it becomes more complex as war conditions can become chaotic in seconds. This habit makes them familiar with stressful conditions. Military personnel is described as having better resilience (Elder and Clipp, 1989) and better handling of traumatic situations (Aldwin et al., 1994). This stress management is also supported by other studies (Hartley et al., 2013; Ivie and Garland, 2011) that imply that a military experience in police officers makes them calmer in handling some stress compared to others. Uncertainties in the form of substantial influence of external and unpredictable factors also force military leaders to precisely adapt to and analyze the situation and formulate it into an appropriate strategy (Simeone, 2020). Military personnel will carefully examine each action's consequences as implementing the wrong tactic in a warzone could be fatal not only for themselves but also their team or even their state.

Another metric of military personnel in a business that is interesting to be researched is their misaligned core values. A joint project of SHRM Foundation and NAVSO in 2017 published a report that focused on reintegrating veterans into the workforce. The report stated that an additional core value that needs to be adopted by veterans is continual innovation as this value is thriving in the business community. This unaligned value sheds light that employing veterans may pose a potential challenge related to a firm's innovationbased investment policy, especially if they hold a crucial position within the organizational structure. This challenge is presented as referring back to the centralized decision-making military structure (Ault, 2003), where military personnel may tend to wait for an order rather than innovate a new tactic by themselves, except in a dire situation. The military also takes a conservative position (Franke, 2001) as they are used to getting new and unknown weapons, demanding lengthy tests (Adamsky, 2020). This value is surely incongruous with business practices that tend to maintain a rapid pace in innovation. These characteristics indeed will indirectly affect corporate investment policy if they are seated as one of the decision-makers.

\section{Military connection studies and setting in Indonesia}

A notable study that examines the military connection in a firm is by Benmelech and Frydman (2015), which found military CEOs who pursue lower corporate investment are less likely to be involved in fraudulent corporate activity and perform better during industry downturns. Following this, several studies have begun to examine other characteristics of military connection and its relationship with corporates, such as tax avoidance (Law and Mills, 2017), financial misconduct (Koch-Bayram and Wernicke, 2018), securities class action lawsuit (Simpson and Sariol, 2019), interest rates (Harymawan, 2018), CSR disclosure (Nasih et al., 2019) and auditor choice (Harymawan, 2020). A recent study examines China's military- 
connected firms' innovation intensity by emphasizing their risk-averse traits (Guo et al., 2020). These studies conjecture an essential insight that military connection in business has proliferated for the past five years.

If traced back to its origin, the military connection in business topics is crossed with political connection studies. In an Indonesian context, Fisman (2001) examined firms connected with Suharto, an Indonesian President with a dominating military background who reigned for over 30 years. Even though he used the political connection term in his study and did not mention any terms related to the military, numerous business sectors were managed by military factions (Xueying, 2014). This interrelation is also supported by Faccio (2006) and Harymawan et al. (2020), who developed and used a measurement for politically connected firms, one of which is based on their closeness to a top official. In the Suharto regime, individuals with a pivotal position in military forces were undoubtedly linked to Suharto, who had the highest authority in the Indonesian government and tended to have several corporates to ensure financial conditions.

Despite the Suharto regime coming to an end in 1998, the Indonesian military influence in business cannot be perceived to have ended instantly. There were heavy resistances from the military as the business reform would be detrimental for their extensive network of formal and informal enterprises. They tried to circumvent government initiatives to control military businesses (Mietzner, 2006; Mietzner and Misol, 2012). As a result, numerous high-ranking military officers still dominate business sectors through various indirect ownerships (Misol, 2010; Xueying, 2014), even up until today (Harymawan, 2020). This dominance is also indirectly reflected in the Indonesian government's central role. Since 2004, at least one of the presidential candidates and ministry heads has had a military background. Therefore, based on these explanations, it can be concluded that Indonesia provides a unique setting for military connection study.

In conjunction with military intervention in Indonesian business, Indonesia's technological innovation environment is appealing for a research setting. Indonesia ranked 80th in technological readiness from 137 countries worldwide surveyed and lagged in the worldwide median [2]. This rank is supported by a survey of more than 2,000 business leaders conducted by General Electric (2018), which shows business leaders from other countries view that Indonesia has yet to establish a conducive environment for innovation. Furthermore, $79 \%$ of Indonesia's business executives state the internal inertia and the incapacity to be nimble, failing at rapidly converting ideas into actions is a challenge. This proportion scores $17 \%$ points higher than the global average $(62 \%)$. This uncertainty is worsened as there are inconsistencies among Indonesian innovation policymakers, leading to a lack of coordination and agreement [3]. Competing perspectives on innovation priorities across both the private and public sectors result in inefficiencies. This unpredictable milieu raises whether allocating a large budget for innovation activities is a wise strategy.

\section{Hypothesis development}

Schumpeter (1947) defined innovation as simply doing new things or doing things that are already being done in a new way. Innovation is the main engine for the firm to sustain in the face of tight competition. A sufficient level of technological innovation in knowledge, technology and value creation is one of the crucial factors if firms want to maintain and grow their financial condition and sustainability (Zhang and Tang, 2017). If a firm fails to comply with the innovation demand, it will provide an unfavorable outcome for the firms, such as a lack of competitive advantages or diminishing corporate reputation (Duane Ireland and Webb, 2007). This threat is well-considered by the stakeholders, but, unfortunately, handling activities related to innovation creation is not as simple as their risk nature, especially in an unstable technology environment such as Indonesia. Several cases are documented where 
firms are experiencing failure one after another as they have not completely comprehended the risk behind innovation activities and merely supplied an ample sum of money to finance these activities (Amoako-Gyampah et al., 2018). Sampson (2007) also argues that research and development activities do not assuredly enhance a firm's financial performance, exceptionally if the activities are not maintained well.

Aware of the innovation activities risk, a military-experienced board will not leave this issue uncontrolled. Top managers' military experience can temper their will, cultivate responsibility and introduce highly individualized thinking patterns and preference characteristics, which ultimately affect their innovative behavior (Guo et al., 2020). This behavior was built during their previous military career where every act if not well thought out could lead to a fatal outcome such as loss of comrades' lives in a warzone. This consistent demand for a careful thinking framework drives soldiers to comprehensively analyze and comprehend any and every potential threat from an innovation activity, even after they quit their military careers (Simeone, 2020). They are also known for their calmness (Hartley et al., 2013) in handling uncertainties, leading to their conservatism behavior. Conservative business leaders are documented as avoiding a high-risk strategy (Benmelech and Frydman, 2015), including less prioritizing its innovation intensity. They perceive these activities as possessing a higher threat to the firm's financial condition than focusing on its potential benefits.

The SHRM Foundation and NAVSO (2017) report show that one of the veterans' challenges to transition into the business profession is developing continual innovation. This result is due to the military centralized command structure (Ault, 2003), where most decisions are based on a top-down approach. For instance, a soldier tends not to question the strategy adopted by their superior and not taking any action based on their improvisation that might contradict the headquarters' order. This behavior gradually constructs a mindset for soldiers (including veterans) to not innovate carelessly, even after being positioned as business leaders. Wait and see is a preferable strategy for them rather than aggressively innovating without proper analysis, especially in new technology (Adamsky, 2020).

An additional rationale that drives a military-experienced board to be conservative in perceiving innovation intensity investment is taking full responsibility for their actions as one of the military core values. This value could mislead into excessive effort to advocate honor (Guo et al., 2020). On the other hand, the military profession also guides cadets to prioritize maintaining their reputable image and use it to earn high praise from society as a hero (Jordan, 2012; Shepherd et al., 2019). These phenomena potentially lead to risk-averse behavior that could impair their pride. A failure is not an option for them, and this is in contrast with innovation intensity investment, where uncertainty is its main trait. Unsuccessful investment intensity investment not only brings unneeded expense for the firm but is also detrimental for corporate reputation, specifically for their militaryexperienced board like the one which taking responsibility for the investment.

Furthermore, military personnel lack technical skills directly related to business (Guo et al., 2020). For instance, financial, accounting, marketing and other expertise, including expertise on certain business-related technologies, could lead to innovation, such as blockchain and business analytics. The new science of these skills leads to a greater uncertainty level when allocating a firm's resources for innovation intensity investment. This drawback makes military-experienced boards biased when considering the value of the innovation intensity investment as they possess limited knowledge of it. They will tend to avoid the investment that is not well-recognized, and for them, it is customary to prefer an investment that is well-known instead of an investment with full of uncertainty.

These explanations conclude that military personnel has conservative traits (Benmelech and Frydman, 2015), and it is confirmed by Franke's (2001) survey on the United States Military Academy at West Point, which found that one of the military cadets' core values is conservatism. Therefore, we posit the hypothesis: 
H1. Firms with military-experienced top management tend to have lower innovation intensity level due to their risk-averse behavior.
Innovation intensity

\section{Research design}

Sample selection procedure and data source

Our sample selection procedure is reported in Table 1 (panel A). Financial accounting data were collected from Osiris database, while, for executive profile, data were gathered manually from firms annual reports. Our sample initially entailed 5,550 firm-year observations of Indonesian-listed firms over the 2010-2018 period. However, we removed 1,438 observations that classified as financial industries (SIC 6). We also removed firm-years for which any variable was missing from Eq. (1) and (2) below, amounting to 1,613 and 1,608. Therefore, our final sample consists of 2,499 firm-year observations for Eq. (1) and 2,504 firm-year observations for Eq. (2).

Table 1 (panel B) reports the industry breakdown of the firm-year observations in the sample using the single-digit SIC codes. Amongst the eight remaining industries, manufacturing (SIC 2) is most broadly represented in the sample, totaling 675 firm-year observations, followed by other industry that falls under manufacturing (SIC 3) of 424 firmyear observations, and mining and construction (SIC 1) of 418 firm-year observations.

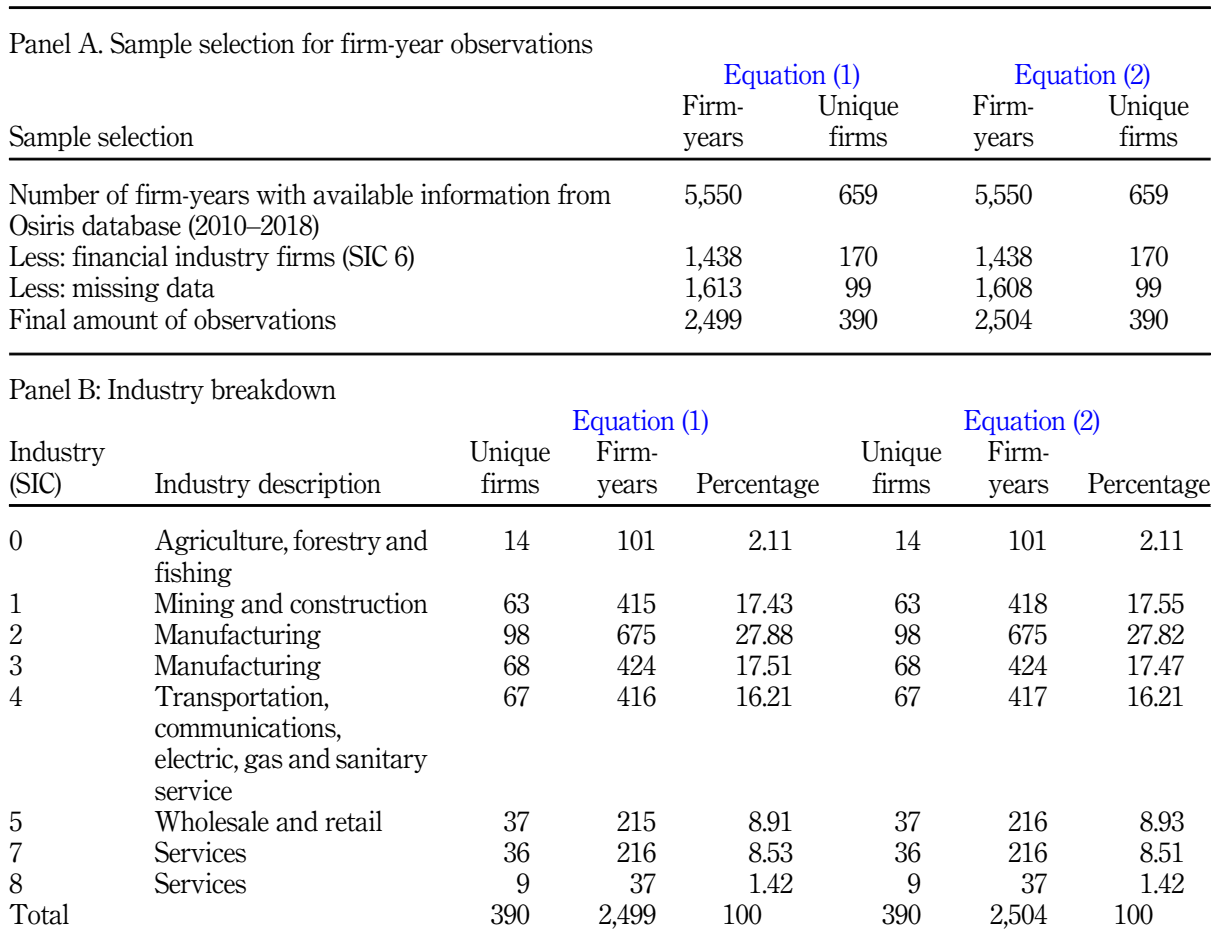

Note(s): This table reports the sample selection for the 2010-2018 and industry breakdown of the sample firms. Panel A reports the selection of firm-year observations for the regression analyses in this study. Panel B reports the industry breakdown of the firms and firm-year observations. The industry classification is based on single-digit SIC code. Firms with code 6 (Financials) are excluded from the sample

Table 1 Sample selection and industry breakdown 
Dependent variables

We use two measurements to determine the level of a firm's innovation intensity. Consistent with the previous literature (Xue, 2007), we employ research and development expense (RND) and intangible asset amount (INTAN). We select these two measurements of the firm's innovation intensity level based on our preliminary research in the Indonesian setting as only those two data are available in the firm's annual reports. RND is measured by deflating the amount of research and developed expense with total sales, while INTAN is measured by deflating the amount of intangibles asset with the firm's total fixed asset. Although we selected these two measurements based on the greatest data availability, $27 \%$ of our initial sample did not disclose the required information.

\section{Independent variables}

Our independent variable is denoted by firm military connection (MCON). We using a dichotomous variable as suggested by previous related studies (e.g. Benmelech and Frydman, 2015; Harymawan, 2020; Simpson and Sariol, 2019). We examine the profile of corporate boards and audit committees to examine the existence of military background. Indonesia has adopted a two-tier governance system in which the board of directors will hold the function of management (BOD), including $\mathrm{CEO}, \mathrm{CFO}$, etc., while the supervisory function is held by the board of commissioners (BOC) (IFC, 2018). Furthermore, it is stated that one of BOC's responsibilities is to ensure that firm's investment planning is appropriately developed. Specifically, Indonesia's Financial Services Authority stated that one of the audit committee's duties and responsibilities is to review the implementation of internal audit and risk management practices (IFC, 2018). Therefore, one of their scopes is also ensuring the firm's investment amount. Those arguments made this study using these three positions as a firm military connection's measurement basis. If one of the mentioned persons has military experience before taking the current position, the firm will be valued one and will be valued zero if stated otherwise. We manually search the individual's military experience on the respective firm's annual report and other possible, reliable sources on the Internet (e.g. LinkedIn and national news). We did not consider the portion of military connection within the firm's board or audit committee. This decision was taken as we argue that it would be less effective to have more than one individual with military experience in influencing corporate innovation intensity level. In addition, as far as we know, there is no prior literature utilizing the portion of the military-connected board within a firm to measure the firm's military connection.

\section{Control variables}

Our control variables are categorized into three groups, namely, innovation-related, governance-related and firm-level-related. We argue these variables could be related to the firm's innovation intensity level, either based on prior literature or our rationale. In the first category, which is innovation-related variable, we use the industry's digital level (TECH) constructed by Calvino et al. (2018), which OECD authorizes. Their analysis divides industries into four levels of digital intensity using two digits of ISIC. Therefore, we convert the ISIC codes into SIC codes, and based on that, we manually categorize the digital intensity of each SIC. Calvino et al.'s (2018) industry's digital intensity taxonomy that employs doubledigit ISIC codes is provided in Appendix 1. We argue that the digitalization of peers within the same industry will encourage them to adapt to these environments. Firms within an industry with a high level of digital intensity will tend to increase their innovation intensity level to preserve their market position, and an innovation enhancement budget will be one of the firm's top priorities to be allocated.

Our second control variable category is the governance-related variable. Based on prior research (Benmelech and Frydman, 2015; Guo et al., 2020; Harymawan et al., 2020), 
several governance-related variables have been used to control innovation intensity level, namely, BOD, BOC, audit committee (AUCOM) and public accountant firm size (BIG4). Total numbers of these positions will improve the possibilities of individuals dedicated to managing innovation investment policy. As for the public accounting firm, the Big 4 is believed to have better monitoring and consulting capability than the non-Big 4 (Donelson et al., 2020; Huang et al., 2020), leading to a higher level of innovation. Therefore, we argue that these variables will be positively related to a firm's innovation intensity.

Our last control variable category is the firm-level-related variable. This category consists of firm size (FSIZE), leverage (LEV), tangible asset (PPE) and total long-term liabilities (LNLOAN). These variables are selected following Harymawan et al. (2020), who used it as a control variable for RND expense variables. We believe that large firms possess higher freedom to allocate budget, including toward firm's innovation, increasing it. As for leverage, this is used to examine the firm's capital structure as firms that rely more on the debt will prioritize paying its interest over other needs, such as financing the innovation-related expenditures. Property, plant and equipment variables indirectly represent how the firm depends on machinery, closely related to technology. Therefore, a firm with a higher amount of tangible assets tends to have a higher innovation intensity level. Lastly, the long-term liabilities are expected capital sources to finance research and development activities as these activities mostly have more than one year to complete the research. Our variable definition is provided in Appendix 2 of this article.

\section{Research design}

We use OLS regression analysis to test our hypothesis in an Indonesian setting. We employ two equations to test our hypothesis, respectively. The regression equations are as follows:

$$
\mathrm{RND}_{i, t}=\beta_{0}+\beta_{1} \mathrm{MCON}_{i, t}+\beta_{2-11} \mathrm{CONTROLS}_{i, t}+\beta_{12} \mathrm{YEAR}_{i, t}+\beta_{13} \mathrm{INDUSTRY}_{i, t}+\varepsilon
$$

$\operatorname{INTAN}_{i, t}=\beta_{0}+\beta_{1} \mathrm{MCON}_{i, t}+\beta_{2-11} \mathrm{CONTROLS}_{i, t}+\beta_{12} \mathrm{YEAR}_{i, t}+\beta_{13} \mathrm{INDUSTRY}_{i, t}+\varepsilon$

\section{Main results}

\section{Descriptive statistics}

We provide our summary of data characteristics in Table 2. Our initial analysis shows that Indonesia's military-connected firms' amount is $22 \%$, while Harymawan (2018) documents that Indonesia's military-connected firms from 2004 to 2012 account for only $4.73 \%$. This proportion difference is different from Benmelech and Frydman's (2015) argument, which states military intervention as business leaders have a diminishing trend compared to prior years, at least in an Indonesian context. Therefore, it could be additional evidence that selecting veterans as one of a firm's top management is increasing in Indonesia and making Indonesia a suitable setting for military-connected firms' study. In panel B, we can see in the military-connected firms' sample that innovation intensity proxy has lower mean values compared to nonmilitary-connected firms' sample. We also identify that firms that position veterans as a top management team have lower industry digital level mean value (1.782) than those who do not (1.996).

\section{Univariate analysis}

In this study, we select two univariate analyses, namely a two-sample $t$-test and Pearson correlation. Based on Table 2 panel $\mathrm{C}$, we find a significant difference with a negative coefficient of RND between nonmilitary-connected firms with military-connected firms. We also find several significant differences between nonmilitary-connected firms with firms
Innovation intensity 


\begin{tabular}{lcccr}
\hline Panel A: Descriptive statistics for full sample & & & \\
& Mean & Median & Minimum & Maximum \\
\hline RND & 0.229 & 0.000 & 0.000 & 10.341 \\
INTAN & 0.020 & 0.000 & 0.000 & 0.343 \\
MCON & 0.220 & 0.000 & 0.000 & 1.000 \\
TECH & 1.949 & 2.000 & 1.000 & 4.000 \\
BOD & 4.765 & 5.000 & 2.000 & 10.000 \\
BOC & 4.307 & 4.000 & 2.000 & 10.000 \\
AUCOM & 3.099 & 3.000 & 2.000 & 5.000 \\
BIG4 & 0.399 & 0.000 & 0.000 & 1.000 \\
ROA & 3.042 & 2.785 & -34.680 & 1.300 \\
LOSS & 0.241 & 0.000 & 0.000 & 1.000 \\
FSIZE & 21.679 & 21.664 & 0.005 & 25.269 \\
LEV & 0.593 & 0.526 & 14.368 & 24.970 \\
PPE & 20.388 & 20.532 & 12.385 & 23.394 \\
LNLOAN & 19.043 & 19.255 & & \\
\hline
\end{tabular}

Panel B: Descriptive statistics for split sample

\begin{tabular}{|c|c|c|c|c|c|c|c|c|}
\hline & \multirow{2}{*}{\multicolumn{3}{|c|}{ MCON sample }} & \multirow[b]{2}{*}{ Max } & \multicolumn{4}{|c|}{ Non-MCON sample } \\
\hline & & & & & Mean & Med & Min & $\operatorname{Max}$ \\
\hline RND & 0.111 & 0.000 & 0.000 & 10.341 & 0.262 & 0.000 & 0.000 & 10.341 \\
\hline INTAN & 0.018 & 0.000 & 0.000 & 0.343 & 0.021 & 0.000 & 0.000 & 0.343 \\
\hline TECH & 1.782 & 1.000 & 1.000 & 4.000 & 1.996 & 2.000 & 1.000 & 4.000 \\
\hline BOD & 5.154 & 5.000 & 2.000 & 10.000 & 4.655 & 4.000 & 2.000 & 10.000 \\
\hline $\mathrm{BOC}$ & 4.811 & 5.000 & 2.000 & 10.000 & 4.165 & 3.000 & 2.000 & 10.000 \\
\hline AUCOM & 3.212 & 3.000 & 2.000 & 5.000 & 3.067 & 3.000 & 2.000 & 5.000 \\
\hline BIG4 & 0.463 & 0.000 & 0.000 & 1.000 & 0.381 & 0.000 & 0.000 & 1.000 \\
\hline ROA & 2.474 & 2.930 & -34.680 & 37.300 & 3.202 & 2.750 & -34.680 & 37.300 \\
\hline LOSS & 0.281 & 0.000 & 0.000 & 1.000 & 0.229 & 0.000 & 0.000 & 1.000 \\
\hline FSIZE & 22.210 & 22.212 & 17.692 & 25.269 & 21.529 & 21.530 & 17.692 & 25.269 \\
\hline LEV & 0.631 & 0.524 & 0.044 & 7.687 & 0.582 & 0.526 & 0.005 & 19.970 \\
\hline PPE & 21.019 & 21.084 & 14.707 & 24.624 & 20.210 & 20.332 & 14.368 & 24.624 \\
\hline LNLOAN & 19.459 & 19.660 & 12.385 & 23.394 & 18.926 & 19.118 & 12.385 & 23.394 \\
\hline
\end{tabular}

Panel C: 2-sample $t$-test

\begin{tabular}{lcr} 
& Coef & $t$-value \\
\hline RND & $-0.151^{* * *}$ & -2.565 \\
INTAN & -0.003 & -0.968 \\
TECH & $-0.214^{* * *}$ & -4.324 \\
BOD & $0.499^{* * *}$ & 5.701 \\
BOC & $0.646^{* * *}$ & 7.798 \\
AUCOM & $0.145^{* * *}$ & 6.444 \\
BIG4 & $0.082^{* * *}$ & 3.472 \\
ROA & -0.728 & -1.558 \\
LOSS & $0.052^{* *}$ & 2.519 \\
FSIZE & $0.681^{* * *}$ & 8.738 \\
LEV & 0.049 & 1.296 \\
PPE & $0.809^{* * *}$ & 8.376 \\
LNLOAN & $0.533^{* * *}$ & 5.221
\end{tabular}

Note(s): This table reports the summary of data used in this study. This table is divided into two panels where panel A for statistic descriptive of 2,610 firm-year observations (total sample), while panel B for statistic descriptive for split sample based on whether firms have a military-experienced board or not. This table also provides the result of a two-sample $t$-test to provide a univariate analysis of this study. The total observations for the MCON sample are 551 firm-year observations, and the non-MCON sample is 1,953 firm-year

Table 2.

Descriptive statistics observations. This test was done after winsorizing the data for 1 and $99 \%$ ${ }^{*} p<0.1,{ }^{* * *} p<0.05,{ }^{* * * *} p<0.01$ 
which have military-experienced top management, such as TECH, BOD, BOC, AUCOM, BIG4, LOSS, FSIZE, PPE and LNLOAN.

We provide the Pearson correlation test result in Table 3 as a second univariate test. Based on Table 3, we find a significant negative relationship between MCON and RND $(p=0.010)$. This result confirms that in both univariate tests, the negative relationship between MCON and RND is consistent. We document other significant negative relationships, for instance, LOSS and LEV with RND, LEV with INTAN and TECH with MCON. Additional significant positive relationships are also documented between BOD, BOC and ROA with RND; TECH, BOD, BOC, AUCOM and FSIZE with INTAN; and BOD, BOC, AUCOM, BIG4, LOSS and LEV with MCON. Overall, both univariate test results show that a military-connected firm tends to have a lower level of innovation activities proxied with RND. In comparison, regarding innovation output (INTAN), a military-connected firm does not have a significant difference with firms without military connection. To conclude, the univariate test shows inconsistencies in support the hypothesis as we only found the desired result in RND when using two-sample $t$-test and in INTAN when using Pearson correlation. This difference drives us further to examine the relationship using multivariate analysis.

\section{Multivariate analysis}

Table 4 provides us the result of hypothesis testing using OLS regression. We find significant negative relationship between military-connected firms with both innovation intensity proxies, namely RND (coeff. $=-0.130, t=-3.09$ ) and INTAN (coeff. $=-0.007, t=-2.75$ ). With coefficient 0.130 in RND, it means that RND differences in military-connected firms and nonmilitary-connected are $13 \%$ of sales. The military-experienced board's presence decreases the intangible asset by $0.7 \%$ from total assets. These percentages are considered substantial change as RND and INTAN's average values from Table 2 are only 22.9 and $2.2 \%$, respectively. Thus, the average value of RND and INTAN's proportion is dominated by the existence of top management's military experience, which is $56.77 \%$ for RND and $31.82 \%$ for INTAN.

The regression result confirms that veterans positioned as a top management team are risk-averse and, at the same time, able to influence the innovation intensity investment policy of the firm. Thus, our hypothesis in this study is not rejected. Besides, we document adjusted $R^{2}$ increases in both equations after adding the MCON variable, which implies that MCON has explanatory power in terms of RND and INTAN.

\section{Robustness Tests}

We employ several endogeneity tests to ensure minimized endogeneity issues in our results. The endogeneity tests used include propensity score matching (PSM) regression, CEM regression, Heckman two-stage regression and change analysis regression. These tests are essential as real-world data indicate that firms do not emerge randomly or uniformly worldwide. Similarly, individuals are not randomly assigned postings or uniformly develop managerial traits (Reeb et al., 2012). Thus, if there are no further tests regarding endogeneity issues, our analysis violates the necessary conditions to make them a valid test (Roberts and Whited, 2013).

\section{Propensity score matching and coarsened exact matching regression}

PSM is believed one of the tools applicable to deal with the self-selection bias problem. According to Lawrence et al. (2011), PSM effectively eliminates the Big 4 public accounting firm's effect on client characteristics. Inspired by their research, this study employs a similar method that is beginning to gain popularity among business scholars. We argue that this test 
\begin{tabular}{l} 
IJMF \\
\\
\hline
\end{tabular}

Table 3.

Pearson correlation

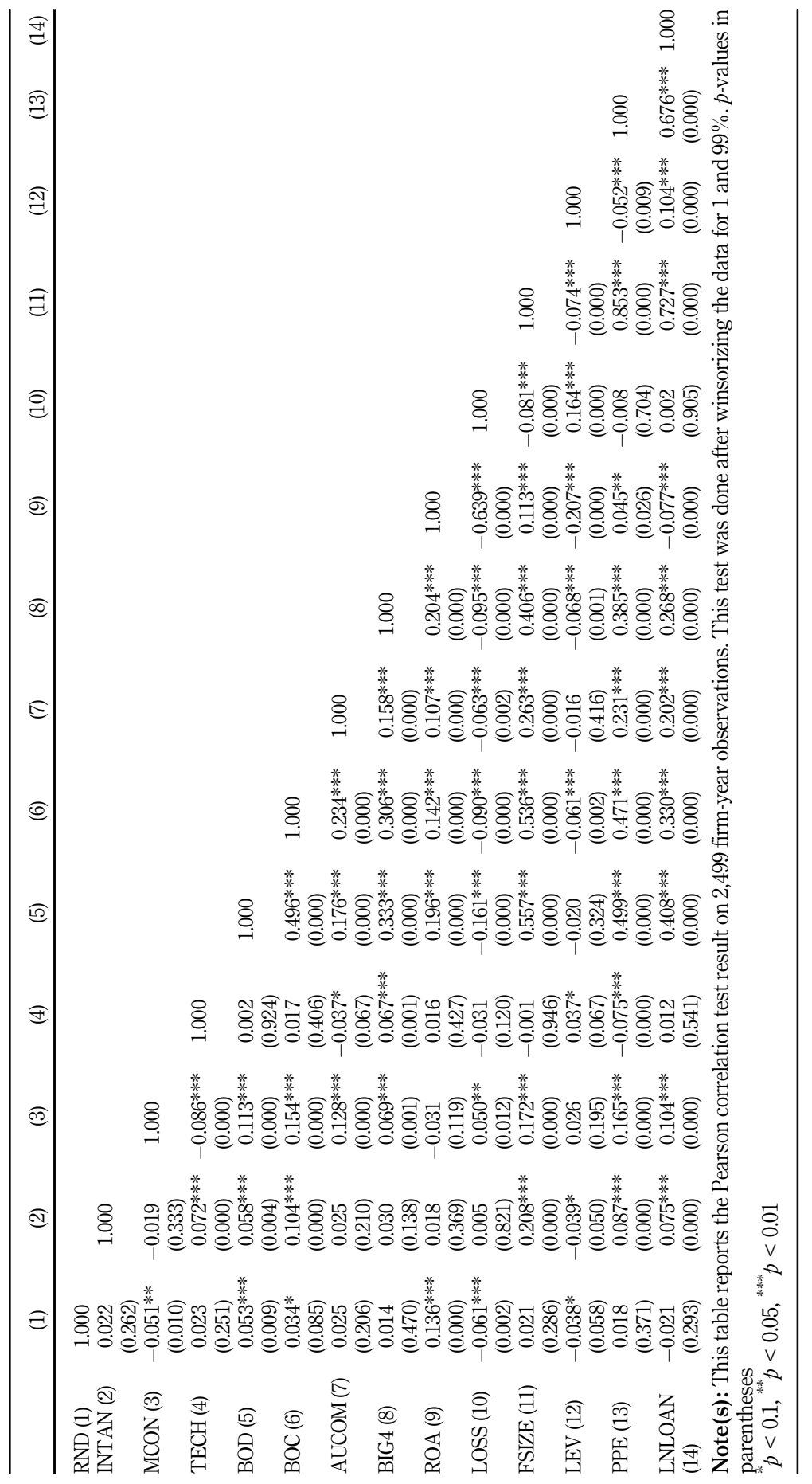




\begin{tabular}{|c|c|c|c|c|}
\hline & $\begin{array}{c}(1) \\
\text { RND }\end{array}$ & $\begin{array}{c}(2) \\
\text { RND }\end{array}$ & $\begin{array}{c}\text { (3) } \\
\text { INTAN }\end{array}$ & $\begin{array}{l}(4) \\
\text { INTAN }\end{array}$ \\
\hline $\mathrm{MCON}$ & & $\begin{array}{l}-0.130 \text { **** } \\
(-3.09)\end{array}$ & & $\begin{array}{l}-0.007^{\text {**** }} \\
(-2.75)\end{array}$ \\
\hline TECH & $\begin{array}{l}0.048^{* * *} \\
(2.33)\end{array}$ & $\begin{array}{l}0.042^{* * *} \\
(2.01)\end{array}$ & $\begin{array}{l}0.005 * * * \\
(3.45)\end{array}$ & $\begin{array}{l}0.005^{* * * *} \\
(3.23)\end{array}$ \\
\hline BOD & $\begin{array}{c}0.013 \\
(0.62)\end{array}$ & $\begin{array}{l}0.013 \\
(0.66)\end{array}$ & $\begin{array}{l}-0.001 * \\
(-1.71)\end{array}$ & $\begin{array}{l}-0.001 * \\
(-1.66)\end{array}$ \\
\hline $\mathrm{BOC}$ & $\begin{array}{c}0.014 \\
(0.88)\end{array}$ & $\begin{array}{c}0.016 \\
(1.01)\end{array}$ & $\begin{array}{c}0.001 \\
(0.82)\end{array}$ & $\begin{array}{c}0.001 \\
(0.96)\end{array}$ \\
\hline AUCOM & $\begin{array}{c}0.063 \\
(1.19)\end{array}$ & $\begin{array}{c}0.073 \\
(1.38)\end{array}$ & $\begin{array}{l}-0.004^{*} \\
(-1.67)\end{array}$ & $\begin{array}{l}-0.004 \\
(-1.46)\end{array}$ \\
\hline BIG4 & $\begin{array}{l}-0.029 \\
(-0.72)\end{array}$ & $\begin{array}{l}-0.031 \\
(-0.77)\end{array}$ & $\begin{array}{l}-0.004 \\
(-1.53)\end{array}$ & $\begin{array}{l}-0.004 \\
(-1.57)\end{array}$ \\
\hline ROA & $\begin{array}{l}0.018^{* * * *} \\
(2.88)\end{array}$ & $\begin{array}{l}0.017^{* * * *} \\
(2.87)\end{array}$ & $\begin{array}{c}0.000 \\
(1.01)\end{array}$ & $\begin{array}{c}0.000 \\
(0.93)\end{array}$ \\
\hline LOSS & $\begin{array}{c}0.120 \\
(1.40)\end{array}$ & $\begin{array}{c}0.127 \\
(1.47)\end{array}$ & $\begin{array}{c}0.005 \\
(1.59)\end{array}$ & $\begin{array}{l}0.005^{*} \\
(1.70)\end{array}$ \\
\hline FSIZE & $\begin{array}{c}0.050 \\
(1.29)\end{array}$ & $\begin{array}{c}0.054 \\
(1.39)\end{array}$ & $\begin{array}{l}0.017^{* * * *} \\
(7.07)\end{array}$ & $\begin{array}{l}0.017^{* * * *} \\
(7.14)\end{array}$ \\
\hline LEV & $\begin{array}{l}-0.021 \\
(-1.28)\end{array}$ & $\begin{array}{l}-0.019 \\
(-1.14)\end{array}$ & $\begin{array}{l}-0.002^{* * * *} \\
(-3.37)\end{array}$ & $\begin{array}{l}-0.002^{* * *} \\
(-3.14)\end{array}$ \\
\hline PPE & $\begin{array}{l}-0.027^{*} \\
(-1.73)\end{array}$ & $\begin{array}{l}-0.026^{*} \\
(-1.65)\end{array}$ & $\begin{array}{l}-0.007^{* * * *} \\
(-4.26)\end{array}$ & $\begin{array}{l}-0.007^{* * * *} \\
(-4.23)\end{array}$ \\
\hline LNLOAN & $\begin{array}{l}-0.042^{* * *} \\
(-2.22)\end{array}$ & $\begin{array}{l}-0.044^{* *} \\
(-2.27)\end{array}$ & $\begin{array}{l}-0.002^{* * *} \\
(-2.38)\end{array}$ & $\begin{array}{l}-0.002^{* * *} \\
(-2.44)\end{array}$ \\
\hline Year FE & $\begin{array}{r}\text { Yes } \\
\text { Yes }\end{array}$ & $\begin{array}{r}\text { Yes } \\
\text { Yes }\end{array}$ & $\begin{array}{r}\text { Yes } \\
\text { Yes }\end{array}$ & $\begin{array}{r}(-2.44) \\
\text { Yes }\end{array}$ \\
\hline Industry FE & Yes & Yes & Yes & Yes \\
\hline$F$ & 3.308 & 3.212 & 9.605 & 9.259 \\
\hline Adjusted $R^{2}$ & 0.057 & 0.059 & 0.123 & 0.125 \\
\hline$N$ & 2,499 & 2,499 & 2,504 & 2,504 \\
\hline
\end{tabular}

Innovation intensity

Note(s): This table reports the result of OLS regression for hypothesis testing of this study. Column 1 and 2 specifically examining the innovation activities (RND), while column 3 and 4 are examining the innovation output (INTAN). This test was done after winsorizing the data for 1 and $99 \% . t$ statistics in parentheses ${ }^{*} p<0.1,{ }^{* * *} p<0.05,{ }^{* * * *} p<0.01$

Table 4. Regression result

is vital as other observed firm characteristics can influence the level of innovation intensity instead of the military connection variable itself. The PSM method is applied using logit regression and with a replacement matching algorithm. We use the 0.01 caliper value to improve the quality of matching and enforces common support because treated cases without untreated cases within the 0.01 caliper value are discarded. The logit regression model is presented below:

$$
\ln \left(\frac{\mathrm{MCON}_{i, t}}{1-\mathrm{MCON}_{i, t}}\right)=\beta_{0}+\beta_{1-10} \operatorname{CONTROLS}_{i, t}+\beta_{11} \operatorname{INDUSTRY}_{i, t}+\varepsilon
$$

The logit regression result and the two-sample $t$-test results of matched sample have been presented in Appendix 3 and 4, respectively. Finally, we provide the result of PSM regression in Table 5 below:

Based on Table 5, we document insignificant relationship between military connection with innovation activities (coeff. $=-0.069, t=-1.15$ ). In contrast, we found a significant negative relationship regarding innovation output (coeff. $=-0.007, t=-2.03$ ), which 


\begin{tabular}{|c|c|c|}
\hline & $\begin{array}{c}(1) \\
\text { RND }\end{array}$ & $\begin{array}{c}(2) \\
\text { INTAN }\end{array}$ \\
\hline MCON & $\begin{array}{l}-0.069 \\
(-1.15)\end{array}$ & $\begin{array}{l}-0.007 * * \\
(-2.03)\end{array}$ \\
\hline TECH & $\begin{array}{c}0.023 \\
(0.81)\end{array}$ & $\begin{array}{l}0.009 * * * \\
(2.98)\end{array}$ \\
\hline BOD & $\begin{array}{l}-0.004 \\
(-0.13)\end{array}$ & $\begin{array}{c}0.001 \\
(0.85)\end{array}$ \\
\hline $\mathrm{BOC}$ & $\begin{array}{c}0.015 \\
(0.64)\end{array}$ & $\begin{array}{l}-0.000 \\
(-0.17)\end{array}$ \\
\hline AUCOM & $\begin{array}{l}0.031 \\
(0.62)\end{array}$ & $\begin{array}{l}-0.004 \\
(-1.35)\end{array}$ \\
\hline BIG4 & $\begin{array}{l}0.007 \\
(0.14)\end{array}$ & $\begin{array}{l}-0.000 \\
(-0.06)\end{array}$ \\
\hline ROA & $\begin{array}{c}0.013 \\
(1.45)\end{array}$ & $\begin{array}{l}0.001^{* * * *} \\
(2.90)\end{array}$ \\
\hline LOSS & $\begin{array}{c}0.160 \\
(1.29)\end{array}$ & $\begin{array}{l}0.010 * * \\
(2.28)\end{array}$ \\
\hline FSIZE & $\begin{array}{c}0.039 \\
(1.00)\end{array}$ & $\begin{array}{l}0.014^{* * * *} \\
(3.62)\end{array}$ \\
\hline LEV & $\begin{array}{l}0.020 \\
(0.73)\end{array}$ & $\begin{array}{l}-0.001 \\
(-0.83)\end{array}$ \\
\hline PPE & $\begin{array}{c}0.000 \\
(0.01)\end{array}$ & $\begin{array}{l}-0.006^{* *} \\
(-2.10)\end{array}$ \\
\hline LNLOAN & $\begin{array}{l}-0.027 \\
(-1.04)\end{array}$ & $\begin{array}{l}-0.002 \\
(-1.56)\end{array}$ \\
\hline Year FE & Yes & Yes \\
\hline Industry FE & Yes & Yes \\
\hline$F$ & 1.128 & 5.293 \\
\hline Adjusted $R^{2}$ & 0.028 & 0.137 \\
\hline$N$ & 929 & 929 \\
\hline
\end{tabular}

Table 5.

Propensity score matching regression

Note(s): This table reports the results of the propensity score matching regression test using 929 firm-year observations. The decreased amount of observations due to PSM requirements for observations to classify matched by PSM. This test was done after winsorizing the data for 1 and $99 \%$. $t$ statistics in parentheses ${ }^{*} p<0.1,{ }^{* * *} p<0.05,{ }^{* * * *} p<0.01$

partially supports our hypothesis. For additional observed variables self-selection bias test, we employ CEM regression to enhance our robustness test result. CEM is believed more eminent than PSM as the PSM design choice has several weaknesses, i.e. matching with or without replacement, the number of additional variables in the model, the number of iterations and bootstrapping analysis (Harymawan, 2018). Our CEM regression result is provided in Table 6. Our CEM test employs TECH, BOD, BOC, AUCOM, ROA, LEV, PPE and LNLOAN for matched variables based on five strata.

Unlike the PSM result, we find a higher level of robustness results in the CEM test result. We find significant negative relation between military connection with both innovation intensity proxies, namely RND (coeff. $=-0.133, t=-2.14$ ) and INTAN (coeff. $=-0.006, t=-1.67$ ). This result confirms that using a matched approach, our argument where firms are headed by an ex-military personnel has low interest in innovation intensity investment policy is confirmed. This could indicate that militaryconnected firms implement a wait-and-see approach in the context of innovation as it is used in their boards based on prior experience in the military profession, as highlighted in the second section of this study. 


\begin{tabular}{|c|c|c|}
\hline & $\begin{array}{c}(1) \\
\text { RND }\end{array}$ & $\begin{array}{c}(2) \\
\text { INTAN }\end{array}$ \\
\hline MCON & $\begin{array}{l}-0.133^{* *} \\
(-2.14)\end{array}$ & $\begin{array}{l}-0.006^{*} \\
(-1.67)\end{array}$ \\
\hline TECH & $\begin{array}{l}0.150 * * \\
(2.05)\end{array}$ & $\begin{array}{c}0.003 \\
(1.27)\end{array}$ \\
\hline BOD & $\begin{array}{c}0.003 \\
(0.10)\end{array}$ & $\begin{array}{l}-0.002^{*} \\
(-1.78)\end{array}$ \\
\hline $\mathrm{BOC}$ & $\begin{array}{c}0.029 \\
(1.10)\end{array}$ & $\begin{array}{c}0.001 \\
(0.48)\end{array}$ \\
\hline AUCOM & $\begin{array}{c}0.088 \\
(1.23)\end{array}$ & $\begin{array}{l}-0.011^{\text {** }} \\
(-2.07)\end{array}$ \\
\hline BIG4 & $\begin{array}{l}-0.132 * * \\
(-2.05)\end{array}$ & $\begin{array}{l}-0.006 \\
(-1.61)\end{array}$ \\
\hline ROA & $\begin{array}{c}0.008 \\
(1.01)\end{array}$ & $\begin{array}{c}0.000 \\
(0.27)\end{array}$ \\
\hline LOSS & $\begin{array}{l}-0.013 \\
(-0.13)\end{array}$ & $\begin{array}{c}0.006 \\
(1.01)\end{array}$ \\
\hline FSIZE & $\begin{array}{l}0.200^{* * * *} \\
(2.84)\end{array}$ & $\begin{array}{l}0.024^{* * * *} \\
(5.01)\end{array}$ \\
\hline LEV & $\begin{array}{l}-0.178 * * \\
(-2.49)\end{array}$ & $\begin{array}{c}0.005 \\
(1.12)\end{array}$ \\
\hline PPE & $\begin{array}{l}-0.110^{* * * *} \\
(-2.94)\end{array}$ & $\begin{array}{l}-0.013^{* * *} \\
(-3.21)\end{array}$ \\
\hline LNLOAN & $\begin{array}{l}-0.127 * * \\
(-2.52)\end{array}$ & $\begin{array}{l}-0.002 \\
(-1.19)\end{array}$ \\
\hline $\begin{array}{l}\text { Year FE } \\
\text { Industry FE }\end{array}$ & $\begin{array}{l}\text { Yes } \\
\text { Yes }\end{array}$ & $\begin{array}{l}\text { Yes } \\
\text { Yes }\end{array}$ \\
\hline$F$ & 1.669 & 5.110 \\
\hline $\begin{array}{l}\text { Adjusted } R^{2} \\
N\end{array}$ & $\begin{array}{c}0.064 \\
1,072\end{array}$ & $\begin{array}{l}0.169 \\
1,074\end{array}$ \\
\hline
\end{tabular}

Innovation intensity

Note(s): This table reports the results of CEM regression test using 1,072 firm-year observations for first equation model and 1,074 firm-year observations for the second one. The CEM test is based on all control variables used in the model and using five strata as basis. The decreased amount of observations due to several requirements in CEM for observations in order to classified matched by CEM. This test was done after winsorizing the data for 1 and $99 \%$. $t$ statistics in parentheses

${ }^{*} p<0.1,{ }^{* * *} p<0.05,{ }^{* * * *} p<0.01$

Table 6.

Coarsened exact matching regression

\section{Heckman two-stage regression}

Following prior studies examining a firm's military connection (Harymawan, 2020; Nasih et al., 2019), we argue there are possibilities of unobserved variables that could influence the innovation intensity and military connection variable. Unobserved variables are known as variables that are not included in the main regression model but may have a relationship with the dependent variable. In addition, hiring management with military experience also exposed with self-selection bias issue as firms are freely choose whether they employ management with or without military experience. When combined, it is possible that the one who has relationship with innovation intensity is not the military connection itself, but it is the unobserved variables. Therefore, we employ Heckman's two-stage regression analysis to address this issue to minimize the occurrence of undesired relationship sources from military connection traits instead of military connections. We employ two instrumental variables originally derived from Kim and Zhang (2016): MDISTANCE, representing the natural logarithm of kilometers distance between firms' HQ with the nearest military base, and PROBCONNECT, which measures by 
the percentage of military-connected firms in a single industry and year. To be more specific, we calculate PROBCONNECT for firm $i$ in industry $j$; we exclude the firm $i$ 's MCON value.

We argue that firms' HQ's closer distance with the nearest military base will make firms recruit veterans. This argument is based on the increases in the probability of similar area operations, which may benefit the firms if they have a well-known military. The argument is also indirectly supported by Cooper et al. (2010), who found a firm's tendencies to employ politicians when they are located in the same state. Furthermore, several industries that often intersect with several regulations (mining, property, import and export, etc.) may have favorable if they hired military-connected persons to ease their bureaucracy process (Mietzner and Misol, 2012). Therefore, the tendency of hiring top management with military experience will be boasted if their competitors within same industry do the exact same strategy as it will benefiting them. These two variables are believed not to directly correlate with a firm's innovation intensity level except through the military connection variable itself. Our Heckman two-stage regression analysis is provided in Table 7.

Our Heckman two-stage regression analysis shows that PROBCONNECT has significant positive relationship at $1 \%$ level with MCON (coeff. $=2.205, t=3.60$ ), while the other instrumental variable, MDISTANCE, does not show significant relationship in first column (coeff. $=0.009, t=0.49$ ). This result implies that the competitor's military-experienced board within the same industry drives firms to recruit veterans as one of their top management teams as expected. On the other hand, our prediction for the relationship between MDISCTANCE and MCON has not been proven. One plausible explanation is firm's location is decided to achieve specific strategic benefits such as an advantage in the transfer pricing system, corporate tax rates and industrial structure (Ishikawa, 2015). Therefore, the close distance between firms' HQ with the nearest military base is more to coincidence than deliberately, and it is not automatically not making firms recruit veterans as their top management.

In the second stage of regression, we find significant negative relationship between MCON with RND (coeff. $=-0.131, t=-3.00$ ) and with INTAN (coeff. $=-0.008, t=-2.91$ ). In regard of MILLS, it shows insignificant result on RND (coeff. $=0.758, t=0.51$ ) but has statistically significant result on INTAN (coeff. $=0.124, t=2.05$ ). This result confirms that our model result in the main analysis did not fully experience endogeneity issue, specifically unobserved variables issue, as the result is consistent but the MILLS variable in INTAN model shown statistically significant result.

\section{Change regression}

Our last robustness examination is through change analysis. Lai et al. (2019) argue that change analysis is an approach establishing causality between CEO's characteristics and their firms' behavior within the same firm. Adopting this rationale, we suggest the extent that firms' risk orientations do not dramatically shift in a short period; a change in innovation intensity accompanying a change of military-experienced top management would suggest a causal relationship. In this analysis, we follow Lai et al. (2019), which only includes firms that recruited ex-military minimum for one year and maximum eight years during the nine years study period. As a result, we only include 593 firm-year observations for the first model and 594 for the second model, instead of 2,499 and 2,504 for each model.

Based on Table 8, we find consistent results in the second research equations proposed with the main analysis result (coeff. $=-0.116, t=-1.71$ ). On the other hand, the RND model has an insignificant result with a coefficient $-0.073(t=-0.95)$. This result suggests that when a firm replaces nonmilitary top management with a military one, its tendency to realize innovation output is weaker, and vice versa. This relationship is due to conservative traits of militaristic top management that could change the realization requirement of certain innovation projects into assets. 


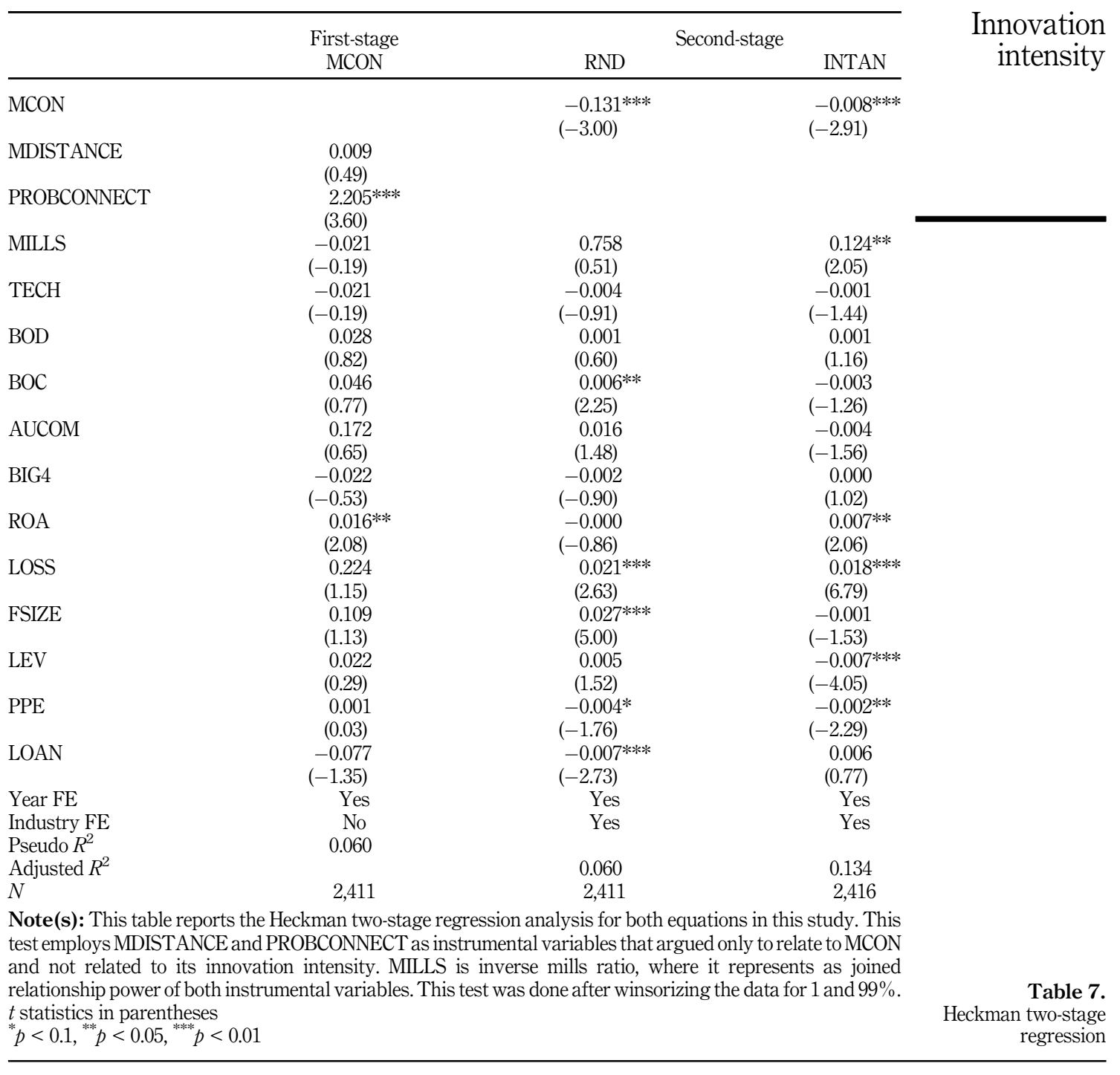

\section{Additional analysis}

We employ four additional analyses to enhance the profundity of relationships between military-connected firms with the firm's innovation intensity. First, we split our sample based on the industry's digital level to examine the relationship in each level of digitalization. Second, we separate the military connection based on its position within a firm. We adopt a similar approach with a second additional analysis for the third, but we focus on military affiliation during top management's military career. The last additional analysis examines the effect of newly appointed military business leaders. 


\begin{tabular}{lcc}
\hline & $(1)$ & $(2)$ \\
& $\Delta$ RND & $\Delta$ INTAN \\
\hline$\Delta$ MCON & -0.073 & $-0.116^{*}$ \\
& $(-0.95)$ & $(-1.71)$ \\
$\Delta$ BOD & 0.141 & 0.144 \\
& $(0.87)$ & $(0.89)$ \\
$\Delta$ BOC & 0.021 & 0.032 \\
& $(0.57)$ & $(0.78)$ \\
$\Delta$ AUCOM & 0.048 & $0.173^{*}$ \\
& $(0.79)$ & $(1.83)$ \\
$\Delta$ BIG4 & -0.103 & -0.048 \\
& $(-1.65)$ & $(-0.76)$ \\
$\Delta$ ROA & $-0.006 * *$ & $-0.007^{* *}$ \\
& $(-2.16)$ & $(-2.54)$ \\
LOSS & -0.005 & -0.024 \\
& $(-0.12)$ & $(-0.41)$ \\
FSIZE & 0.048 & 0.097 \\
& $(0.72)$ & $(1.15)$ \\
LEV & 0.064 & -0.052 \\
$\Delta$ PPE & $(1.00)$ & $(-0.86)$ \\
& -0.031 & -0.034 \\
$\Delta$ LNLOAN & $(-1.47)$ & $(-1.53)$ \\
& 0.030 & 0.028 \\
Year FE & $(0.82)$ & $(0.88)$ \\
Industry FE & Yes & Yes \\
$F$ & Yes & Yes \\
Adjusted $R^{2}$ & 0.701 & 1.059 \\
$N$ & -0.002 & 0.030 \\
Note(s): & 593 & 594 \\
& &
\end{tabular}

Table 8.

Change analysis regression

Note(s): This table reports the change analysis regression test using 593 firm-year observations for the first equation and 594 firm-years observations for the second equation. The number of observations is due to excluding any firms that do not recruit any veterans during the study period. This test was done after winsorizing the data for 1 and $99 \% . t$ statistics in parentheses ${ }^{*} p<0.1, \stackrel{* * *}{p} p<0.05,{ }^{* * * *} p<0.01$

\section{Split sample based on industry digital level}

Benmelech and Frydman (2015) found that firms headed by veterans have better performance during the crisis compared to others. They imply this result as military personnel is trained to restrain their panic emotion and enhance their stress management during their career (Aldwin et al., 1994). This argument leads us to conclude that a militaryexperienced individual can think clearly, despite experiencing an external environment, and this capability could lead to better strategy formulating skills for a firm. Based on this assumption, we intend to test the risk-averse innate traits of military-connected firms in an environment that demands high level and continuous innovation. First, we split our sample into two sub-sample based on Calvino et al. (2018) measurement on industry's digital intensity level (low and medium to low are considered low-tech industry, while medium to high and high are considered high-tech industry). Our untabulated result shows that the high-tech firms have a statistically significant lower proportion in military experience (coeff. $=-0.032$, $t=-1.766)$. The statistic result justifies us to continue the test by splitting our sample based on its industry's digital intensity level as constructed by Calvino et al. (2018) into four subsamples.

Table 9 provides the result of split sample regression. Most of our split sample category (low, medium to low and middle to high) shows a negative relationship between military 


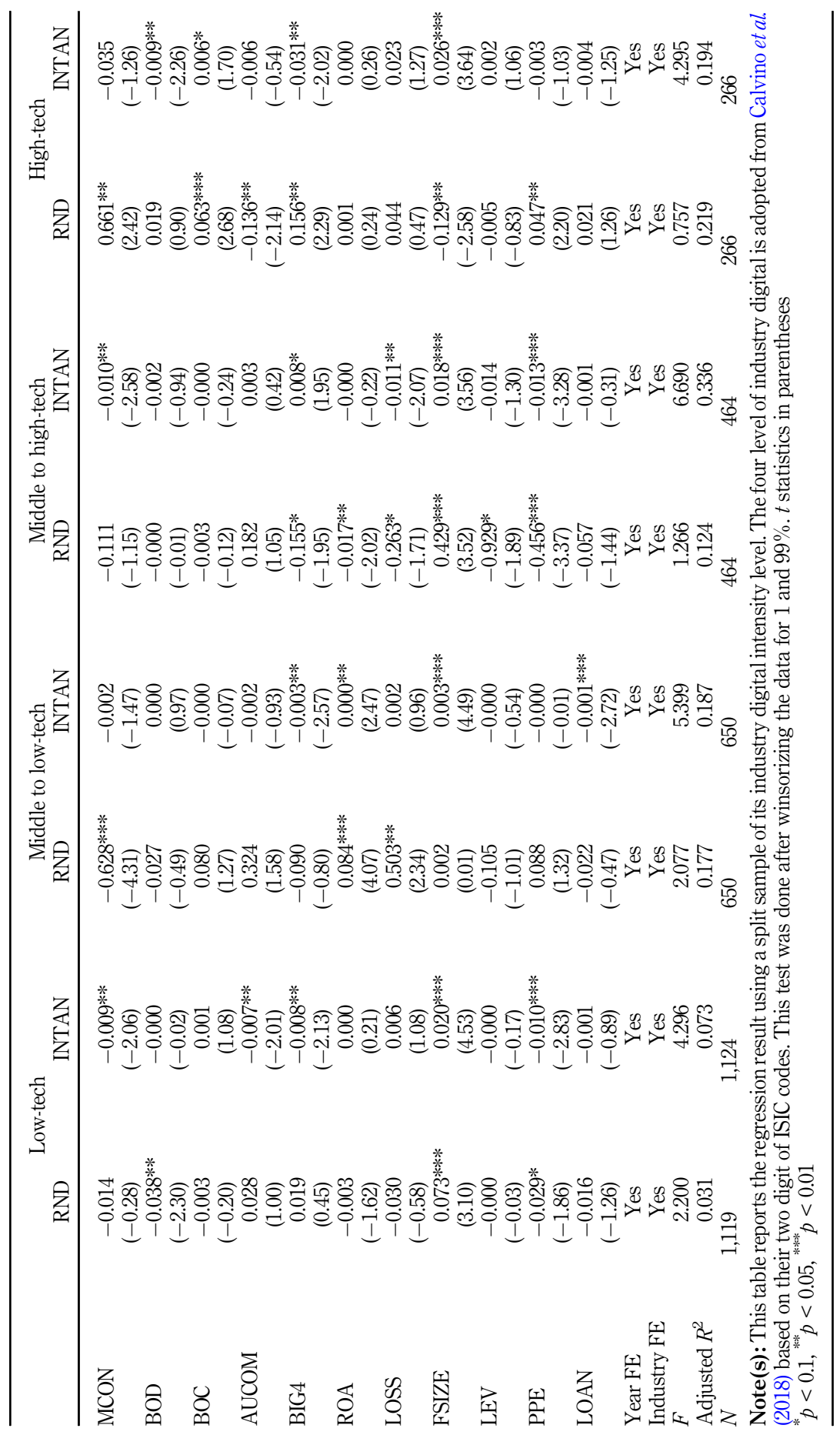

Innovation intensity 
connection with innovation intensity level, especially for innovation product. Nevertheless, in our high-tech sample, we document a significant positive relationship between MCON with $\mathrm{RND}$ (coeff. $=0.661, t=2.42$ ). The split sample regression result in Table 9 confirms our prior prediction, whereby if an ex-military personnel is seated as the firm's board with a high level of digital intensity, it would drastically reshape its risk preference behavior. This changing behavior is believed due to military personnel adapting to a particular environment and formulating an appropriate strategy to address challenges that may appear, including a high expectation of innovation intensity in the high-technology industry.

\section{The corporate position of military-connected person}

As mentioned before, Indonesia adopts a two-tier governance system that compromises BOD and BOC. In addition, the audit committee is also responsible for developing reliable investment planning but has lower jurisdiction than BOC. This difference made us interested in examining the position of a firm's military-experienced person's influence on militaryconnected firms' risk-averse behavior. We employ the specific variable of military connection based on its position within a firm. MCON_BOD precisely if the military-connected person is positioned as one of the board of directors, MCON_BOC for the board of commissioners and MCON_COM for the audit committee. Our regression is separated into two categories where; first, each regression model is exclusively for one type of military connection based on its position, and the second, puts all the variables into a single regression equation. Our regression result is provided in Table 10 .

Based on Table 10, we can conclude that military connection has a significant negative relationship with innovation activities, regardless of its position and regression model categories. In regard to innovation output, only military-connected person positioned on the board of commissioners has negative significant relationship, both in the exclusive model (coeff. $=-0.008, t=-3.05$ ) and in combined model (coeff. $=-0.009, t=-3.41$ ). We posit this result arises as, in the Indonesia setting, the board of commissioners has the highest authority between these three corporate governance organs. Therefore, their influential power is maximized when positioned with high authority, where, in this study context, a risk-averse behavior is reflected by the low level of innovation outputs. Overall, regardless of its position, a military-connected firm tends to limit its innovation intensity level.

\section{The affiliation of military-connected person}

Using a similar approach to previous additional analysis, we wanted to test whether boards' military affiliation influences a military-connected firm's risk-averse behavior. This test adopts the method by Nasih et al. (2019) that splits military affiliation into four: army, navy, air force and police. Specifically, in Indonesia, police are part of the military up to 1999 which it can be said that most of their career value adopted is interrelated (Meliala, 2001). Furthermore, to strengthen argument including police into the military, we conduct untabulated regression test similarly with the preliminary test but the excluding any police in MCON variable. The result shows that MCON has consistent significant relationship with RND (coeff. $=-0.114, t=-2.30$ ) and INTAN (coeff. $=-0.007$, $t=-2.43)$.

We posit that, regardless of affiliation, ex-military personnel still carry out the risk-averse business, leading to a firm's conservatism approach in innovation intensity investment. Our initial result shows 299 observations with army affiliation, 24 air force affiliations, 72 marine affiliations and 189 police affiliations. We provide the test result in Table 11, specifically panel A, for our first equation model that examines innovation activities (RND) and panel B for innovation outputs (INTAN). 


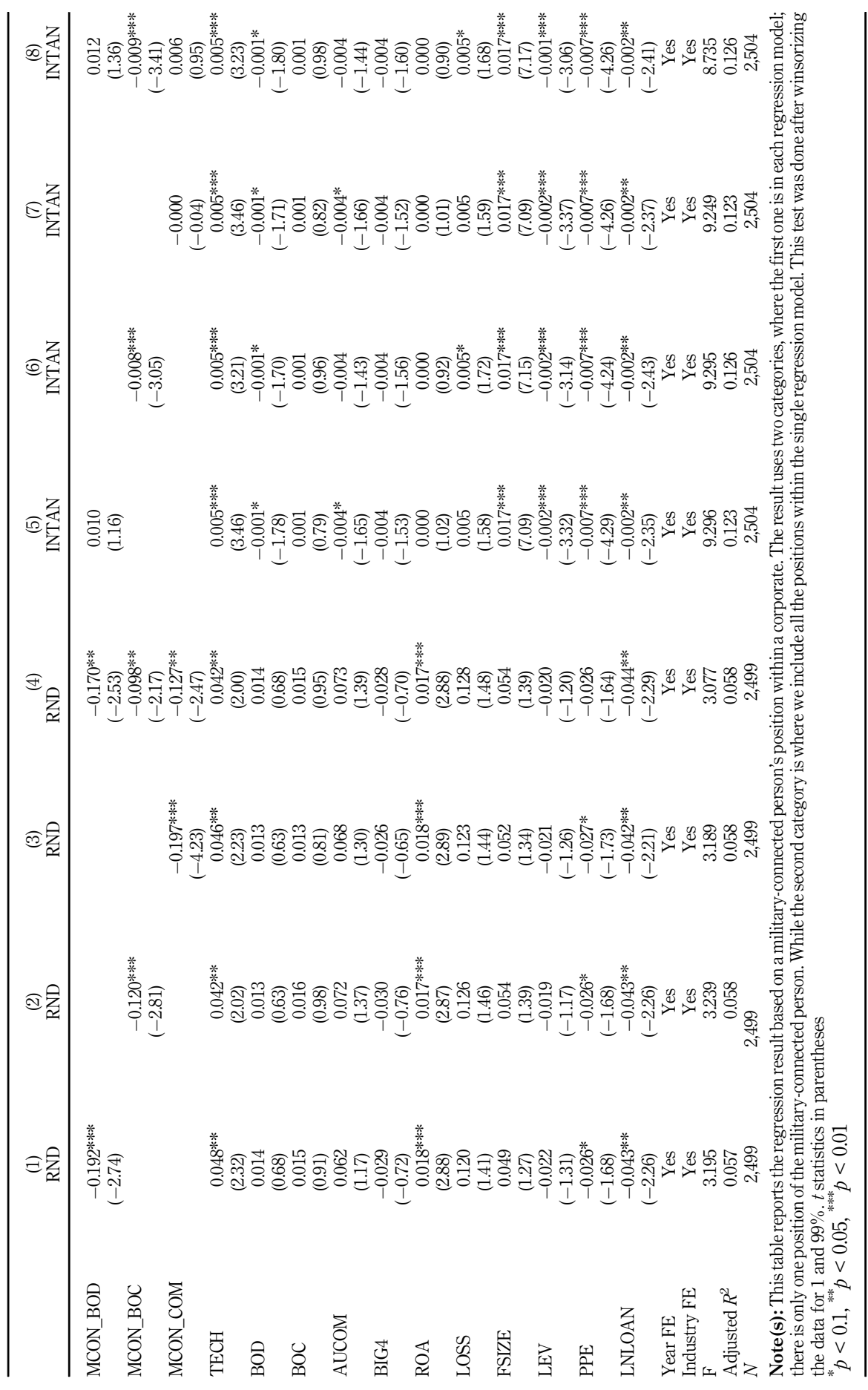

Innovation intensity 


\begin{tabular}{|c|c|c|c|c|c|}
\hline Panel A: Inno & $\begin{array}{l}\text { activities re } \\
\text { (1) } \\
\text { RND }\end{array}$ & $\begin{array}{c}\text { on models } \\
(2) \\
\text { RND }\end{array}$ & $\begin{array}{c}(3) \\
\text { RND }\end{array}$ & $\begin{array}{c}(4) \\
\text { RND }\end{array}$ & $\begin{array}{c}(5) \\
\text { RND }\end{array}$ \\
\hline ARMY & $\begin{array}{l}-0.139 * * \\
(-2.41)\end{array}$ & & & & $\begin{array}{l}-0.138 * * \\
(-2.37)\end{array}$ \\
\hline NAVY & & $\begin{array}{l}-0.111^{*} \\
(-1.74)\end{array}$ & & & $\begin{array}{l}-0.120^{*} \\
(-1.85)\end{array}$ \\
\hline AIR & & & $\begin{array}{l}-0.390 * * * \\
(-4.86)\end{array}$ & & $\begin{array}{l}-0.413^{* * *} \\
(-5.04)\end{array}$ \\
\hline POLICE & & & & $\begin{array}{l}-0.123^{* * * *} \\
(-3.32)\end{array}$ & $\begin{array}{l}-0.120^{\text {**** }} \\
(-3.22)\end{array}$ \\
\hline TECH & $\begin{array}{l}0.043^{* *} \\
(2.07)\end{array}$ & $\begin{array}{l}0.047 \text { ** } \\
(2.27)\end{array}$ & $\begin{array}{l}0.049 * * \\
(2.34)\end{array}$ & $\begin{array}{l}0.047^{* *} \\
(2.25)\end{array}$ & $\begin{array}{l}0.041^{*} \\
(1.96)\end{array}$ \\
\hline BOD & $\begin{array}{c}0.013 \\
(0.66)\end{array}$ & $\begin{array}{c}0.013 \\
(0.62)\end{array}$ & $\begin{array}{c}0.012 \\
(0.59)\end{array}$ & $\begin{array}{c}0.013 \\
(0.62)\end{array}$ & $\begin{array}{c}0.013 \\
(0.63)\end{array}$ \\
\hline $\mathrm{BOC}$ & $\begin{array}{l}0.015 \\
(0.96)\end{array}$ & $\begin{array}{l}0.013 \\
(0.81)\end{array}$ & $\begin{array}{c}0.015 \\
(0.92)\end{array}$ & $\begin{array}{c}0.016 \\
(1.00)\end{array}$ & $\begin{array}{c}0.017 \\
(1.05)\end{array}$ \\
\hline AUCOM & $\begin{array}{l}0.067 \\
(1.28)\end{array}$ & $\begin{array}{l}0.064 \\
(1.21)\end{array}$ & $\begin{array}{l}0.064 \\
(1.21)\end{array}$ & $\begin{array}{c}0.062 \\
(1.17)\end{array}$ & $\begin{array}{l}0.068 \\
(1.29)\end{array}$ \\
\hline BIG4 & $\begin{array}{l}-0.027 \\
(-0.66)\end{array}$ & $\begin{array}{l}-0.026 \\
(-0.64)\end{array}$ & $\begin{array}{l}-0.034 \\
(-0.84)\end{array}$ & $\begin{array}{l}-0.031 \\
(-0.77)\end{array}$ & $\begin{array}{l}-0.030 \\
(-0.74)\end{array}$ \\
\hline ROA & $\begin{array}{l}0.018^{* * * *} \\
(2.89)\end{array}$ & $\begin{array}{l}0.017^{\text {**** }} \\
(2.86)\end{array}$ & $\begin{array}{l}0.018^{* * * *} \\
(2.88)\end{array}$ & $\begin{array}{l}0.018^{* * * *} \\
(2.89)\end{array}$ & $\begin{array}{l}0.018^{* * * *} \\
(2.87)\end{array}$ \\
\hline LOSS & $\begin{array}{c}0.125 \\
(1.45)\end{array}$ & $\begin{array}{l}0.118 \\
(1.39)\end{array}$ & $\begin{array}{c}0.124 \\
(1.45)\end{array}$ & $\begin{array}{c}0.123 \\
(1.43)\end{array}$ & $\begin{array}{c}0.132 \\
(1.52)\end{array}$ \\
\hline FSIZE & $\begin{array}{l}0.054 \\
(1.39)\end{array}$ & $\begin{array}{l}0.049 \\
(1.29)\end{array}$ & $\begin{array}{c}0.054 \\
(1.39)\end{array}$ & $\begin{array}{l}0.050 \\
(1.29)\end{array}$ & $\begin{array}{l}0.058 \\
(1.48)\end{array}$ \\
\hline LEV & $\begin{array}{l}-0.019 \\
(-1.16)\end{array}$ & $\begin{array}{l}-0.020 \\
(-1.21)\end{array}$ & $\begin{array}{l}-0.022 \\
(-1.32)\end{array}$ & $\begin{array}{l}-0.022 \\
(-1.32)\end{array}$ & $\begin{array}{l}-0.019 \\
(-1.15)\end{array}$ \\
\hline PPE & $\begin{array}{l}-0.027^{*} \\
(-1.69)\end{array}$ & $\begin{array}{l}-0.027^{*} \\
(-1.69)\end{array}$ & $\begin{array}{l}-0.028^{*} \\
(-1.79)\end{array}$ & $\begin{array}{l}-0.027^{*} \\
(-1.71)\end{array}$ & $\begin{array}{l}-0.027^{*} \\
(-1.69)\end{array}$ \\
\hline LNLOAN & $\begin{array}{l}-0.044^{* * *} \\
(-2.30)\end{array}$ & $\begin{array}{l}-0.043^{* * *} \\
(-2.23)\end{array}$ & $\begin{array}{l}-0.044^{* *} \\
(-2.29)\end{array}$ & $\begin{array}{l}-0.042^{* *} \\
(-2.18)\end{array}$ & $\begin{array}{l}-0.046^{* *} \\
(-2.36)\end{array}$ \\
\hline Year FE & Yes & Yes & Yes & Yes & Yes \\
\hline Industry FE & Yes & Yes & Yes & Yes & Yes \\
\hline & 3.173 & 3.190 & 3.187 & 3.189 & 2.864 \\
\hline Adjusted $R^{2}$ & 0.058 & 0.057 & 0.058 & 0.058 & 0.059 \\
\hline$N$ & 2,499 & 2,499 & 2,499 & 2,499 & 2,499 \\
\hline \multicolumn{6}{|c|}{ Panel B: Innovation output regression models } \\
\hline & $\begin{array}{c}\text { (6) } \\
\text { INTAN }\end{array}$ & $\begin{array}{c}(7) \\
\text { INTAN }\end{array}$ & $\begin{array}{c}(8) \\
\text { INTAN }\end{array}$ & $\begin{array}{c}(9) \\
\text { INTAN }\end{array}$ & $\begin{array}{c}(10) \\
\text { INTAN }\end{array}$ \\
\hline ARMY & $\begin{array}{l}-0.003 \\
(-0.98)\end{array}$ & & & & $\begin{array}{l}-0.004 \\
(-1.02)\end{array}$ \\
\hline NAVY & & $\begin{array}{l}-0.010^{* * * *} \\
(-3.36)\end{array}$ & & & $\begin{array}{l}-0.010^{* * * *} \\
(-3.41)\end{array}$ \\
\hline AIR & & & $\begin{array}{l}-0.019 * * * \\
(-3.66)\end{array}$ & & $\begin{array}{l}-0.019 * * * \\
(-3.77)\end{array}$ \\
\hline POLICE & & & & $\begin{array}{l}-0.002 \\
(-0.44)\end{array}$ & $\begin{array}{l}-0.002 \\
(-0.47)\end{array}$ \\
\hline TECH & $\begin{array}{l}0.005^{* * * *} \\
(3.38)\end{array}$ & $\begin{array}{l}0.005^{* * * *} \\
(3.38)\end{array}$ & $\begin{array}{l}0.005^{* * * *} \\
(3.46)\end{array}$ & $\begin{array}{l}0.005^{* * * *} \\
(3.43)\end{array}$ & $\begin{array}{l}0.005^{* * * *} \\
(3.30)\end{array}$ \\
\hline BOD & $\begin{array}{l}-0.001 * \\
(-1.69)\end{array}$ & $\begin{array}{l}-0.001 * \\
(-1.70)\end{array}$ & $\begin{array}{l}-0.001 * \\
(-1.75)\end{array}$ & $\begin{array}{l}-0.001 * \\
(-1.71)\end{array}$ & $\begin{array}{l}-0.001^{*} \\
(-1.72)\end{array}$ \\
\hline & & & & & (continued) \\
\hline
\end{tabular}

Table $\mathbf{1 1}$.
Regression based on military affiliation 


\begin{tabular}{lccccc}
\hline \multirow{2}{*}{ Panel B: Innovation output regression models } & & & & \\
& $(6)$ & $(7)$ & $(8)$ & $(9)$ & $(10)$ \\
& INTAN & INTAN & INTAN & INTAN & INTAN \\
\hline BOC & 0.001 & 0.001 & 0.001 & 0.001 & 0.001 \\
& $(0.86)$ & $(0.70)$ & $(0.86)$ & $(0.85)$ & $(0.81)$ \\
AUCOM & -0.004 & -0.004 & $-0.004^{*}$ & $-0.004^{*}$ & -0.004 \\
& $(-1.62)$ & $(-1.63)$ & $(-1.66)$ & $(-1.67)$ & $(-1.57)$ \\
BIG4 & -0.003 & -0.003 & -0.004 & -0.004 & -0.003 \\
& $(-1.50)$ & $(-1.40)$ & $(-1.62)$ & $(-1.54)$ & $(-1.48)$ \\
ROA & 0.000 & 0.000 & 0.000 & 0.000 & 0.000 \\
& $(1.00)$ & $(0.92)$ & $(1.00)$ & $(1.02)$ & $(0.91)$ \\
LOSS & 0.005 & 0.005 & $0.005^{*}$ & 0.005 & $0.005^{*}$ \\
& $(1.63)$ & $(1.55)$ & $(1.66)$ & $(1.60)$ & $(1.68)$ \\
FSIZE & $0.017^{* * *}$ & $0.017^{* * *}$ & $0.017^{* * *}$ & $0.017^{* * *}$ & $0.017^{* * * *}$ \\
& $(7.12)$ & $(7.07)$ & $(7.11)$ & $(7.07)$ & $(7.15)$ \\
LEV & $-0.002^{* * * *}$ & $-0.002^{* * *}$ & $-0.002^{* * *}$ & $-0.002^{* * * *}$ & $-0.002^{* * * *}$ \\
& $(-3.26)$ & $(-3.16)$ & $(-3.41)$ & $(-3.36)$ & $(-3.09)$ \\
PPE & $-0.007^{* * * *}$ & $-0.007^{* * * *}$ & $-0.007^{* * *}$ & $-0.007^{* * * *}$ & $-0.007^{* * * *}$ \\
& $(-4.25)$ & $(-4.23)$ & $(-4.29)$ & $(-4.26)$ & $(-4.24)$ \\
LNLOAN & $-0.002^{* * *}$ & $-0.002^{* * *}$ & $-0.002^{* *}$ & $-0.002^{* * *}$ & $-0.002^{* * *}$ \\
& $(-2.43)$ & $(-2.41)$ & $(-2.47)$ & $(-2.36)$ & $(-2.54)$ \\
Year FE & Yes & Yes & Yes & Yes & Yes \\
Industry FE & Yes & Yes & Yes & Yes & Yes \\
F & 9.313 & 9.352 & 9.311 & 9.246 & 8.530 \\
Adjusted $R^{2}$ & 0.123 & 0.124 & 0.124 & 0.123 & 0.124 \\
$N$ & 2,504 & 2,504 & 2,504 & 2,504 & 2,504 \\
& & & & &
\end{tabular}

Note(s): This table reports the regression result based on military-connected person's affiliation during their military career. Following Nasih et al. (2019), we adopt four affiliations: army, navy, air force and police. Panel A in this table is specifically for innovation activities (RND), while panel B for innovation outputs (INTAN). This test was done after winsorizing the data for 1 and $99 \%$. $t$ statistics in parentheses

${ }^{*} p<0.1,{ }^{* * *} p<0.05,{ }^{* * * *} p<0.01$

Table 11.

In panel $\mathrm{A}$, we identify that all military affiliation types show a significant negative relationship with innovation activities. This could indicate that for most military personnel, regardless of their affiliation, the risk-averse behavior is constructed and still carried out even after they no longer have a military career. In regard to innovation outputs, we also identify significant negative relationship between military personnel from navy (coeff. $=-0.010, t=-3.41$ ) and air force (coeff $=-0.019, t=-3.77$ ) with INTAN in combined model. Overall, our results in Table 11 partially support our prior argument that all military affiliations show a negative coefficient, although several are not statistically significant.

\section{New appointed military-connected management}

In this sub-section, we are interested in testing the influential power of military-connected persons toward the firm's innovation intensity investment policy. Several studies document that newly appointed management may not have sufficient power to reshape corporate policy. It needs longer tenure to gain influential power. Although there are no compelling theoretical arguments for why any one of these measures should be more appropriate than another, Lewellyn and Muller-Kahle (2012) document a consistency in using tenure to measure management power. Thus, tenure is one of the critical reflections of management power. However, concerning veterans seated as firm's top management, this argument may not apply as they likely have strong leadership and command skill above average (Shepherd 
et al., 2019). Aware of this contradiction between these two streamlines, we develop a new variable, namely NEW_MCON, where it is valued by one if a firm appointed new management with military experience or 0 if stated otherwise in the current year. The variable is used to empirically test if veterans' leadership style can overcome tenure's needs to influence innovation intensity investment policy. We identify that during our sample period 111 firms recruit top management teams with military experience. Our result is presented in Table 12.

Surprisingly, our results show significant negative relationship between recent appointment of top management that has military experience with innovation activities (coeff. $=-0.107, t=-2.15$ ) and insignificant result with innovation outputs (coeff. $=-0.001, t=-0.21$ ). This result confirms that military personnel has exceptional influential power toward firms' innovation intensity investment policy. Although we did not find a negative relationship in innovation outputs, Table $12 \mathrm{implies} \mathrm{that,} \mathrm{in} \mathrm{a} \mathrm{veteran's}$ first year of employment as firm's top management, they can directly reduce the RND expenses, which serves as a representation of their risk-averse trait, but unable to directly adjust the intangibles amount either from capitalization policy or externally acquired.

\begin{tabular}{|c|c|c|}
\hline & $\begin{array}{c}(1) \\
\text { RND }\end{array}$ & $\begin{array}{c}(2) \\
\text { INTAN }\end{array}$ \\
\hline NEW_MCON & $\begin{array}{l}-0.107^{* *} \\
(-2.15)\end{array}$ & $\begin{array}{l}-0.001 \\
(-0.21)\end{array}$ \\
\hline TECH & $\begin{array}{l}0.048^{* *} \\
(2.29)\end{array}$ & $\begin{array}{l}0.005^{* * *} \\
(3.44)\end{array}$ \\
\hline BOD & $\begin{array}{c}0.013 \\
(0.62)\end{array}$ & $\begin{array}{l}-0.001^{*} \\
(-1.71)\end{array}$ \\
\hline $\mathrm{BOC}$ & $\begin{array}{l}0.014 \\
(0.90)\end{array}$ & $\begin{array}{c}0.001 \\
(0.82)\end{array}$ \\
\hline AUCOM & $\begin{array}{c}0.064 \\
(1.22)\end{array}$ & $\begin{array}{l}-0.004^{*} \\
(-1.67)\end{array}$ \\
\hline BIG4 & $\begin{array}{l}-0.029 \\
(-0.72)\end{array}$ & $\begin{array}{c}-0.004 \\
(-1.53)\end{array}$ \\
\hline $\mathrm{ROA}$ & $\begin{array}{l}0.017^{* * * *} \\
(2.86)\end{array}$ & $\begin{array}{c}0.000 \\
(1.00)\end{array}$ \\
\hline LOSS & $\begin{array}{c}0.119 \\
(1.39)\end{array}$ & $\begin{array}{l}0.005 \\
(1.59)\end{array}$ \\
\hline FSIZE & $\begin{array}{c}0.050 \\
(1.29)\end{array}$ & $\begin{array}{l}0.017^{* * *} \\
(7.07)\end{array}$ \\
\hline LEV & $\begin{array}{l}-0.022 \\
(-1.30)\end{array}$ & $\begin{array}{l}-0.002^{* * * *} \\
(-3.36)\end{array}$ \\
\hline PPE & $\begin{array}{l}-0.027^{*} \\
(-1.69)\end{array}$ & $\begin{array}{l}-0.007^{* * * *} \\
(-4.26)\end{array}$ \\
\hline LNLOAN & $\begin{array}{l}-0.042^{* *} \\
(-2.22)\end{array}$ & $\begin{array}{l}-0.002^{* *} \\
(-2.38)\end{array}$ \\
\hline Year FE & Yes & Yes \\
\hline Industry FE & Yes & Yes \\
\hline$F$ & 3.193 & 9.247 \\
\hline Adjusted $R^{2}$ & 0.057 & 0.123 \\
\hline$N$ & 2,499 & 2,504 \\
\hline
\end{tabular}

Table 12.

Regression of new appointed militaryconnected management 


\section{Conclusion and recommendation}

Our study examined the risk preference of military-connected firms, specifically in their innovation intensity investment policy. We use nonfinancial Indonesian-listed firms during 2010-2018 as Indonesia has a long history with military intervention in business and substantial uncertainties in the technology environment. This study confirms that military-connected firms have lower innovation intensity, both in innovation activities and outputs, than firms that do not have any military connection. Our result is robust as we employ several endogeneity tests to minimize the self-selection bias. Furthermore, we employ several additional tests to enhance our understanding of military-connected firms' relationship with innovation intensity.

The importance of the consequences of selecting management with a particular background as a whole cannot be denied. One of these consequences is reflected in a firm's innovation intensity investment policy. This study emphasizes the need to adopt more comprehensive research on the conjunction between management with military experience with firm's investment strategy. It is argued in this paper that research regarding military connection has been too narrow in scope, insofar as it has focused mainly on militaryconnected firms' ethical business conduct. For instance, fraud (Benmelech and Frydman, 2015), after receiving a lawsuit (Simpson and Sariol, 2019), tax avoidance (Law and Mills, 2017), financial misconduct (Koch-Bayram and Wernicke, 2018) and CSR reporting (Nasih et al., 2019). As far as we are aware, only Benmelech and Frydman (2015) and Guo et al. (2020) studied military connection in the context of innovation investment policy. This paper broadens the scope of research by examining the types of military connection and innovation intensity investment. This comprehensive view of the military connection assessment highlights attention regarding each corporate position's military connection and its affiliation during a military career. This study differentiates into two categories that reflect the innovation process or activities and innovation outputs in the context of innovation intensity. This study may point to the strengths and weaknesses in the appointment of management with specific military affiliation and their position.

Further, this study may also offer insight into the ongoing debate about militaryconnected firms' external environment. While the risk-averse behavior of a militaryconnected firm is generally accepted and applied to the innovation intensity setting, it should be emphasized again that risk-averse behavior is less dominant with technology environment adaptation skills of military-experienced management. On the contrary, if the risk-averse behavior of military-connected firm understanding is not followed, the shareholders who select management based on their military experience will be misinterpreted as to its consequences, which could even distract attention from important matters. However, it is essential to consider the current external condition of a firm as it may reflect the alternative taken by a military-connected firm, regardless of their original trait. Thus, these results also emphasize the need to understand better stakeholders' concept of a military-connected firm's risk-averse behavior.

These findings are interesting and important, but specifically for newly appointed military-experienced management, it contradicts several studies. We argue the management tenure reflects their persuasive power toward the corporate policy as it is found consistent in prior studies, despite several management power measurements (Lewellyn and Muller-Kahle, 2012). This is due to recently appointed management having less recognition and being perceived as "freshman" who do not understand the corporate operational and condition comprehensively. This argument, somehow, is not applied if the new management has a military background, at least in diminishing innovation activities. This phenomenon is selfexplanatory as military personnel are perceived as heroes who can plan, lead and take action to achieve the goal settled in an efficient approach (Shepherd et al., 2019). The result underlines that management with a military career may, unlike others, not need some time to redirect the corporate policy.
Innovation intensity 
The finding of this research, nevertheless, need to be understood in light of their limitations. This study does not consider the individual percentage of management with military experience, which is plausibly interrelated with their influence on corporate policy. We encourage future studies to employ this measurement to provide a more comprehensive explanation regarding its relationship. In addition, our measurement of innovation intensity only captures limited types of innovation. We did not consider other innovation varieties, such as knowledge sharing systems, product features, idea delivery systems and many others. Several studies using patent amount as one of the innovation proxies, but only limited Indonesian firms that specifically disclose their patent amount. Thus, future studies are suggested to employ more comprehensive innovation measurements. Our last limitation that is possibly addressed by future studies is considering management compensation. Equity incentives provided to management resulting management may tend to obey shareholders wanted, such as firm's innovation level. Similar to patent data, Indonesian-listed firms are not obliged to disclose their management compensation amount; therefore, only a small portion of it discloses the information.

\section{Notes}

1. The top 26 worldwide companies including AT\&T Inc., Amazon, Cisco System, Ernst and Young LLP, Hewlett-Packard, IBM Corporation, JPMorgan chase and Co., Johnson and Johnson, and many more.

2. Based on World Bank data retrieved from TCdata 360 website (www.tcdata360.worldbank.org) accessed on September 15th, 2020. The data show the 2017 9th pillar of the Country Competitiveness Index for Indonesia and worldwide.

3. This statement is based on several reports generated by Nesta (www.nesta.org.uk), and The Innovation Policy Platform (www.innovationpolicyplatform.org) accessed on September 28th, 2020.

\section{References}

Adamsky, D.D. (2020), "The art of net assessment and uncovering foreign military innovations: learning from Andrew W. Marshall's legacy", Journal of Strategic Studies, Vol. 43 No. 5, pp. 611-644, doi: 10.1080/01402390.2020.1776121.

Aldwin, C.M., Levenson, M.R. and Spiro, A. III (1994), "Vulnerability and resilience to combat exposure: can stress have lifelong effects?", Psychology and Aging, Vol. 9 No. 1, pp. 34-44.

Amoako-Gyampah, K., Meredith, J. and Loyd, K.W. (2018), "Using a social capital lens to identify the mechanisms of top management commitment: a case study of a technology project", Project Management Journal, Vol. 49 No. 1, pp. 79-95, doi: 10.1177/875697281804900106.

Ault, R.T. (2003), "Encouraging risk and embracing uncertainty: the need to change the US army culture", available at: https://www.hsdl.org/?view\&did=815892.

Bell, P., Engel, R., Hudson, D., Jamison, J. and Skimmyhorn, W. (2018), "Risk preferences in future military leaders", Journal of Behavioral Economics for Policy, Vol. 2 No. 2, pp. 11-24, available at: https://sabeconomics.org/wordpress/wp-content/uploads/JBEP-2-2-2.pdf.

Benmelech, E. and Frydman, C. (2015), "Military CEOs", Journal of Financial Economics, Vol. 117 No. 1, pp. 43-59, doi: 10.1016/j.jfineco.2014.04.009.

Calvino, F., Criscuolo, C., Marcolin, L. and Squicciarini, M. (2018), A Taxonomy of Digital Intensive Sectors, Technology and Industry Working Papers, Vol. 14, OECD Science, doi: 10.1787/ f404736a-en.

CareerBuilder (2016), "Annual CareerBuilder survey finds that hiring veterans remains a strong focus, but veteran job satisfaction takes a dip", available at: http://press.careerbuilder.com/pressreleases?item $=123266$. 
Citroën, L. (2018), “5 business lessons I learned working with military veterans”, Entrepreneur, available at: https://www.entrepreneur.com/article/308012.

Cooper, M.J., Gulen, H. and Ovtchinnikov, A.V. (2010), "Corporate political contributions and stock returns”, The Journal of Finance, Vol. 65 No. 2, pp. 687-724, doi: 10.1111/j.1540-6261.2009. 01548.x.

Defence.gov (2015), "Statistical report on the military retirement system: fiscal year 2015", available at: https://actuary.defense.gov/Portals/15/Documents/MRS_StatRpt_2015-Final-v2.pdf?ver=201607-26-162207-987.

Donelson, D.C., Ege, M., Imdieke, A.J. and Maksymov, E. (2020), "The revival of large consulting practices at the Big 4 and audit quality", Accounting, Organizations and Society, Vol. 87, doi: 10.1016/j.aos.2020.101157.

Duane Ireland, R. and Webb, J.W. (2007), "Strategic entrepreneurship: creating competitive advantage through streams of innovation", Business Horizons, Vol. 50 No. 1, pp. 49-59, doi: 10.1016/j. bushor.2006.06.002.

Duffy, T. (2006), Military Experience and CEOs: Is There A Link?, Korn/Ferry International, available at: https://militarymba.net/resources/MilitaryCEOReport.pdf.

Elder, G.H. and Clipp, E.C. (1989), "Combat experience and emotional health: impairment and resilience in later life", Journal of Personality, Vol. 57 No. 2, pp. 311-341, doi: 10.1111/j.1467-6494. 1989.tb00485.x.

Faccio, M. (2006), "Politically connected firms", The American Economic Review, Vol. 96 No. 1, pp. 369-386, doi: 10.1257/000282806776157704.

Fisman, R. (2001), "Estimating the value of political connections", The American Economic Review, Vol. 91 No. 4, pp. 1095-1102, doi: 10.1257/aer.91.4.1095.

Franke, V. (2001), "Generation X and the military: a comparison of attitudes and values between West Point cadets and college students", Journal of Political and Military Sociology, Vol. 29, pp. 92-119.

General Electric (2018), “GE global innovation barometer 2018: Indonesia report”, available at: https:/ www.ge.com/reports/wp-content/themes/gereports2017/assets/innovation-barometer-2018/ reports/Indonesia_Country_Report_Final.pdf.

Gray, K. and Wegner, D.M. (2011), “To escape blame, don't be a hero-Be a victim”, Journal of Experimental Social Psychology, Vol. 47 No. 2, pp. 516-519, doi: 10.1016/j.jesp.2010.12.012.

Gray, K. and Wegner, D.M. (2012), "Morality takes two: Dyadic morality and mind perception", The Social Psychology of Morality: Exploring the Causes of Good and Evil, American Psychological Association, pp. 109-127, doi: 10.1037/13091-006.

Guo, S., Zan, B., Sun, Y. and Zhang, M. (2020), "Effects of top managers' military experience on technological innovation in the transition economies of China", Technological Forecasting and Social Change, Vol. 153, doi: 10.1016/j.techfore.2020.119909.

Hambrick, D.C. (2007), "Upper echelons theory: an update", Academy of Management Review, Vol. 32 No. 2, pp. 334-343, doi: 10.5465/AMR.2007.24345254.

Hartley, T.A., Violanti, J.M., Mnatsakanova, A., Andrew, M.E. and Burchfiel, C.M. (2013), "Military experience and levels of stress and coping in police officers", International Journal of Emergency Mental Health, Vol. 15 No. 4, pp. 229-239, available at: https:/www.scopus.com/ inward/record.uri?eid=2-s2.0-84899143707\&partnerID=40\&md5=1c606ddd7770b80bdc960f93 d3e17a5b.

Harymawan, I. (2018), "Why do firms appoint former military personnel as directors? Evidence of loan interest rate in militarily connected firms in Indonesia", Asian Review of Accounting, Vol. 26 No. 1, doi: 10.1108/ARA-07-2016-0086.

Harymawan, I. (2020), "Military reform, militarily-connected firms and auditor choice", Managerial Auditing Journal, Vol. 35 No. 6, pp. 705-729, doi: 10.1108/MAJ-04-2019-2258. 
Harymawan, I., Putra, F.K.G., Ekasari, W.F. and Sucahyati, D. (2020), "Are independent commissioners able to mitigate higher audit fees in politically connected firms? Evidence from Indonesia”, International Journal of Innovation, Creativity and Change, Vol. 8 No. 11, pp. 24-43.

Huang, P., Wen, Y.-C. and Zhang, Y. (2020), "Does the monitoring effect of Big 4 audit firms really prevail? Evidence from managerial expropriation of cash assets", Review of Quantitative Finance and Accounting, Vol. 55 No. 2, pp. 739-768, doi: 10.1007/s11156-019-00858-9.

IFC (2018), Indonesia Corporate Governance Manual (Second), International Finance Corporation, Jakarta, doi: 10.1596/30122.

Ishikawa, T. (2015), "Firms' location selections and regional policy in the global economy", Firms' Location Selections and Regional Policy in the Global Economy, doi: 10.1007/978-4-431-55366-3.

Ivie, D. and Garland, B. (2011), "Stress and burnout in policing: does military experience matter?", Policing-an International Journal of Police Strategies and Management - POLICING, Vol. 34 No. 1, pp. 49-66, doi: 10.1108/13639511111106605.

Jones, D. (2005), A Vanishing Breed: CEOs Seasoned by Military Combat, USA Today, available at: https:/usatoday30.usatoday.com/money/companies/management/2005-01-18-war-ceo_x.htm.

Jordan, B. (2012), "Poll: America values vets but stereotypes them", available at: https://www.military. com/daily-news/2012/06/14/poll-america-values-vets-but-stereotypes-them.html.

Kellog Insight (2019), “Take 5: what business leaders can learn from the military”, available at: https:// insight.kellogg.northwestern.edu/article/business-lessons-from-military.

Kim, C. (Francis) and Zhang, L. (2016), “Corporate political connections and tax aggressiveness", Contemporary Accounting Research, Vol. 33 No. 1, pp. 78-114, doi: 10.2139/ssrn.2303836.

Koch-Bayram, I.F. and Wernicke, G. (2018), "Drilled to obey? Ex-military CEOs and financial misconduct", Strategic Management Journal, Vol. 39 No. 11, doi: 10.1002/smj.2946.

Lai, S., Li, Z. and Yang, Y.G. (2019), "East, west, home's best: do local CEOs behave less myopically?", The Accounting Review, Vol. 95 No. 2, pp. 227-255, doi: 10.2308/accr-52555.

Law, K.K.F. and Mills, L.F. (2017), "Military experience and corporate tax avoidance", Review of Accounting Studies, Vol. 22, pp. 141-184, doi: 10.1007/s11142-016-9373-z.

Lawrence, A., Minutti-Meza, M. and Zhang, P. (2011), "Can big 4 versus non-big 4 differences in auditquality proxies Be attributed to client characteristics?", The Accounting Review, Vol. 86 No. 1, pp. 259-286, available at: http://www.jstor.org/stable/29780232.

Lewellyn, K.B. and Muller-Kahle, M.I. (2012), "CEO power and risk taking: evidence from the subprime lending industry", Corporate Governance: An International Review, Vol. 20 No. 3, pp. 289-307, doi: 10.1111/j.1467-8683.2011.00903.x.

MacLean, A. and Elder, G.H. Jr (2007), "Military service in the life course”, Annual Review of Sociology, Vol. 33, pp. 175-196, doi: 10.1146/annurev.soc.33.040406.131710.

Meliala, A. (2001), "Police as military: indonesias experience", Policing, Vol. 24 No. 3, pp. 420-431, doi: 10.1108/eum0000000005853.

Mietzner, M. (2006), The Politics of Military Reform in Post-Suharto Indonesia, East-West Center, available at: http://www.jstor.org/stable/resrep06524.

Mietzner, M. and Misol, L. (2012), "Military businesses in post-Suharto Indonesia: decline, reform and persistence", The Politics of Military Reform: Experiences from Indonesia and Nigeria, doi: 10. 1007/978-3-642-29624-6_5.

Misol, L. (2010), "Unkept Promise" Failure to End Military Business Activity in Indonesia, Human Right Watch, available at: https://www.hrw.org/report/2010/01/11/unkept-promise/failure-endmilitary-business-activity-indonesia.

Nasih, M., Harymawan, I., Putra, F.K.G. and Qotrunnada, R. (2019), "Military experienced board and corporate social responsibility disclosure: an empirical evidence from Indonesia", Entrepreneurship and Sustainabilty Issues, Vol. 7 No. 1, pp. 553-573. 
Petersen, M.A. (2009), "Estimating standard errors in finance panel data sets: comparing approaches", Review of Financial Studies, Vol. 22 No. 1, pp. 435-480, doi: 10.1093/rfs/hhn053.

Rand Corporation (2014), "Veteran employement: lessons from the 100,000 jobs mission", available at: https://www.rand.org/content/dam/rand/pubs/research_reports/RR800/RR836/RAND_ RR836.pdf.

Reeb, D., Sakakibara, M. and Mahmood, I.P. (2012), "From the editors: endogeneity in international business research”, Journal of International Business Studies, Vol. 43 No. 3, pp. 211-218, doi: 10. 1057/jibs.2011.60.

Roberts, M.R. and Whited, T.M. (2013), "Chapter 7 - Endogeneity in empirical corporate finance", in Constantinides, G.M., Harris, M. and Stulz, R. (Eds), Handbook of the Economics of Finance, Elsevier, Vol. 2, pp. 493-572, doi: 10.1016/B978-0-44-453594-8.00007-0.

Sampson, R.C. (2007), "R\&D alliances and firm performance: the impact of technological diversity and alliance organization on innovation", Academy of Management Journal, Vol. 50 No. 2, pp. 364-386, doi: 10.5465/AMJ.2007.24634443.

Schein, C. and Gray, K. (2018), "The theory of dyadic morality: reinventing moral judgment by redefining harm”, Personality and Social Psychology Review, Vol. 22 No. 1, pp. 32-70, doi: 10.1177/ 1088868317698288.

Schumpeter, J.A. (1947), "The creative response in economic history", The Journal of Economic History, Vol. 7 No. 2, pp. 149-159, available at: http://www.jstor.org/stable/2113338.

Shepherd, S., Kay, A.C. and Gray, K. (2019), "Organizational Behavior and Human Decision Processes Military veterans are morally typecast as agentic but unfeeling: implications for veteran employment”, Organizational Behavior and Human Decision Processes, Vol. 153, June, pp. 75-88, doi: 10.1016/j.obhdp.2019.06.003.

SHRM Foundation and NAVSO (2017), "Integrating and engaging veterans in the workforce", available at: https:/www.shrm.org/foundation/ourwork/initiatives/engaging-and-integratingmilitary-veterans/Documents/4-17-Vet-Summit-Report-FINAL.pdf.

Simeone, L. (2020), "Characterizing strategic design processes in relation to definitions of strategy from military", Business and Management Studies. The Design Journal, Vol. 23 No. 4, pp. 515-534, doi: 10.1080/14606925.2020.1758472.

Simpson, J. and Sariol, A.M. (2019), "Squared away: veterans on the board of directors", Journal of Business Ethics, Vol. 160, doi: 10.1007/s10551-018-3907-1.

Spiro, A. III and Settersten, R.A. Jr (2012), "Long-term implications of military service for later-life health and well-being", Research in Human Development, Vol. 9 No. 3, pp. 183-190, doi: 10.1080/ 15427609.2012.705551.

US Bureau of Labor Statistics (2020), "Employment situation of veterans summary", available at: https://www.bls.gov/news.release/vet.nr0.htm.

Xue, Y. (2007), "Make or buy new technology: the role of CEO compensation contract in a firm's route to innovation", Review of Accounting Studies, Vol. 12 No. 4, pp. 659-690, doi: 10.1007/s11142-007-9039-y.

Xueying, L. (2014), Indonesian Military's Role in Economy Set to Be Phased Out, The Jakarta Post, available at: https:/www.thejakartapost.com/news/2014/05/23/indonesian-militarys-roleeconomy-set-be-phased-out.html.

Zhang, G. and Tang, C. (2017), "How could firm's internal R\&D collaboration bring more innovation?", Technological Forecasting and Social Change, Vol. 125, pp.299-308, doi:10.1016/j.techfore.2017.07.007.

\section{Corresponding author}

Iman Harymawan can be contacted at: harymawan.iman@feb.unair.ac.id
Innovation intensity 
Table A1.

Taxonomy of digital intensive industries
Appendix 1

\begin{tabular}{|c|c|c|}
\hline Industry denomination & ISIC rev 4 & Quartile of digital intensity \\
\hline Agriculture, forestry, fishing & $01-03$ & Low \\
\hline Mining and quarrying & 05-09 & Low \\
\hline Food products, beverages, and tobacco & $10-12$ & Low \\
\hline Textiles, wearing apparel, leather & $13-15$ & Medium-low \\
\hline Wood and paper products, and printing & $16-18$ & Medium-high \\
\hline Coke and refined petroleum products & 19 & Medium-low \\
\hline Chemicals and chemical products & 20 & Medium-low \\
\hline Pharmaceutical products & 21 & Medium-low \\
\hline Rubber and plastics products & $22-23$ & Medium-low \\
\hline Basic metals and fabricated metal products & $24-25$ & Medium-low \\
\hline Computer, electronic and optical products & 26 & Medium-high \\
\hline Electrical equipment & 27 & Medium-high \\
\hline Machinery and equipment n.e.c & 28 & Medium-high \\
\hline Transport equipment & $39-30$ & High \\
\hline Furniture; other manufacturing; repairs of computers & $31-33$ & Medium-high \\
\hline Electricity, gas, steam and air cond & 35 & Low \\
\hline Water supply; sewerage, waste management & $36-39$ & Low \\
\hline Construction & $41-43$ & Low \\
\hline Wholesale and retail trade, repair & $45-47$ & Medium-high \\
\hline Transportation and storage & $49-53$ & Low \\
\hline Accommodation and food service activities & $55-56$ & Low \\
\hline Publishing, audiovisual and broadcasting & $58-60$ & Medium-high \\
\hline Telecommunications & 61 & High \\
\hline IT and other information services & $62-63$ & High \\
\hline Finance and insurance & $64-66$ & High \\
\hline Real estate & 68 & Low \\
\hline Legal and accounting activities, etc. & $69-71$ & High \\
\hline Scientific research and development & 72 & High \\
\hline Advertising and market research; other business services & $73-75$ & High \\
\hline Administrative and support service activities & $77-82$ & High \\
\hline Public administration and defense & 84 & Medium-high \\
\hline Education & 85 & Medium-low \\
\hline Human health activities & 86 & Medium-low \\
\hline Residential care and social work activities & $87-88$ & Medium-low \\
\hline Arts, entertainment and recreation & $90-93$ & Medium-high \\
\hline Other service activities & $94-96$ & High \\
\hline Source(s): Calvino et al. (2018) & & \\
\hline
\end{tabular}


Appendix 2

\begin{tabular}{|c|c|c|c|}
\hline Variable name & Definition & Source & \\
\hline \multicolumn{4}{|c|}{ Dependent Variable } \\
\hline RND & Research and development expense deflated by total asset & Orbis & \\
\hline INTAN & Total intangible assets deflated by total fixed asset & Orbis & \\
\hline \multicolumn{4}{|l|}{ Interested Variable } \\
\hline MCON & $\begin{array}{l}\text { Valued by } 1 \text { if firm appoint person who has military background as one } \\
\text { of board of directors and/or board of commissioners and/or audit } \\
\text { committee or } 0 \text { if stated otherwise }\end{array}$ & $\begin{array}{l}\text { Annual } \\
\text { Report }\end{array}$ & \\
\hline MCON_BOD & $\begin{array}{l}\text { Valued by } 1 \text { if firm appoint person who has military background as one } \\
\text { of board of directors or } 0 \text { if stated otherwise }\end{array}$ & $\begin{array}{l}\text { Annual } \\
\text { Report }\end{array}$ & \\
\hline MCON_BOC & $\begin{array}{l}\text { Valued by } 1 \text { if firm appoint person who has military background as one } \\
\text { of board of commissioners or } 0 \text { if stated otherwise }\end{array}$ & $\begin{array}{l}\text { Annual } \\
\text { Report }\end{array}$ & \\
\hline MCON_COM & $\begin{array}{l}\text { Valued by } 1 \text { if firm appoint person who has military background as one } \\
\text { of audit committee or } 0 \text { if stated otherwise }\end{array}$ & $\begin{array}{l}\text { Annual } \\
\text { Report }\end{array}$ & \\
\hline ARMY & $\begin{array}{l}\text { Valued by } 1 \text { if firm appoint person who has army military background } \\
\text { as one of board of directors and/or board of commissioners and/or audit } \\
\text { committee or } 0 \text { if stated otherwise }\end{array}$ & $\begin{array}{l}\text { Annual } \\
\text { Report }\end{array}$ & \\
\hline MARINE & $\begin{array}{l}\text { Valued by } 1 \text { if firm appoint person who has marine military background } \\
\text { as one of board of directors and/or board of commissioners and/or audit } \\
\text { committee or } 0 \text { if stated otherwise }\end{array}$ & $\begin{array}{l}\text { Annual } \\
\text { Report }\end{array}$ & \\
\hline AIR & $\begin{array}{l}\text { Valued by } 1 \text { if firm appoint person who has air force military } \\
\text { background as one of board of directors and/or board of commissioners } \\
\text { and/or audit committee or } 0 \text { if stated otherwise }\end{array}$ & $\begin{array}{l}\text { Annual } \\
\text { Report }\end{array}$ & \\
\hline POLICE & $\begin{array}{l}\text { Valued by } 1 \text { if firm appoint person who has police background as one of } \\
\text { board of directors and/or board of commissioners and/or audit } \\
\text { committee or } 0 \text { if stated otherwise }\end{array}$ & $\begin{array}{l}\text { Annual } \\
\text { Report }\end{array}$ & \\
\hline NEW_MCON & $\begin{array}{l}\text { Valued by } 1 \text { if firm appoint person who has military background as one } \\
\text { of board of directors and/or board of commissioners and/or audit } \\
\text { committee in the current year or } 0 \text { if stated otherwise }\end{array}$ & $\begin{array}{l}\text { Annual } \\
\text { Report }\end{array}$ & \\
\hline \multicolumn{4}{|c|}{ Instrumental Variable } \\
\hline MDISTANCE & $\begin{array}{l}\text { Natural logarithm of total distance (kilometers) between firm's HQ with } \\
\text { nearest military base }\end{array}$ & Google maps & \\
\hline PROBCONNECT & Ratio of military-connected firms with total firms amount in each industry & & \\
\hline \multicolumn{4}{|l|}{ Control Variable } \\
\hline $\begin{array}{l}\text { Innovation-related } \\
\text { TECH }\end{array}$ & $\begin{array}{l}\text { Valued based on firm industry's that employ four level of industry } \\
\text { digital intensity level. The four level as follow: low (1), medium-low (2), } \\
\text { medium-high (3), high (4) }\end{array}$ & $\begin{array}{l}\text { Calvino et al. } \\
\text { (2018) }\end{array}$ & \\
\hline \multicolumn{4}{|c|}{ Governance-related } \\
\hline BOD & Size of the board of directors & Annual report & \\
\hline $\mathrm{BOC}$ & Size of the board of commissioners & Annual report & \\
\hline AUCOM & Size of the audit committees & Annual report & \\
\hline BIG4 & $\begin{array}{l}\text { Valued by } 1 \text { if the firm's public accounting firm is one of } \\
\text { PricewaterhouseCoopers, Deloitte, Ernst and Young, and KPMG or } 0 \text { if } \\
\text { stated otherwise }\end{array}$ & Annual report & \\
\hline \multicolumn{4}{|l|}{ Firm-level-related } \\
\hline FSIZE & Natural logarithm of firm's total asset & Orbis & \\
\hline LEV & Total liabilities deflated by total asset & Orbis & \\
\hline PPE & Natural logarithm of firm's total property, plant, and equipment & Orbis & Table A2. \\
\hline LNLOAN & Natural logarithm of firm's long-term loan & Orbis & Variable definition \\
\hline
\end{tabular}


Appendix 3

(1) MCON

\begin{tabular}{lc}
\hline TECH & $-0.309 *$ \\
BOD & $(-1.75)$ \\
& 0.427 \\
BOC & $(0.42)$ \\
& 0.147 \\
AUCOM & $(1.48)$ \\
BIG4 & 0.341 \\
& $(1.21)$ \\
ROA & -0.269 \\
LOSS & $(-0.75)$ \\
FSIZE & 0.202 \\
LEV & $(0.91)$ \\
PPE & 0.238 \\
LNLOAN & $(0.53)$ \\
Industry FE & 0.023 \\
Pseudo $R^{2}$ & $(0.10)$ \\
$N$ & 0.085 \\
Note(s): & $(0.81)$ \\
& 0.143 \\
& $(0.91)$ \\
& 0.170 \\
& $(0.16)$ \\
Y & Yes \\
& 0.078
\end{tabular}

Note(s): This table reports the logit regression result based on logit regression model which the dependent variable has been replaced by military connection. The result is only using 309 firm-years observations which

Table A3.

Logit regression on PSM model fulfilled all the PSM requirement mentioned priorly. This test was done after winsorizing the data for 1 and $99 \%$. $t$ statistics in parentheses ${ }^{*} p<0.1,{ }^{* * *} p<0.05,{ }^{* * * *} p<0.01$ 
Appendix 4

Innovation intensity

\begin{tabular}{lccrr}
\hline & Mean & Mean & & \\
& MCON $=0$ & MCON $=1$ & Coef & $t$-value \\
\hline RND & 0.175 & 0.111 & -0.064 & -1.131 \\
INTAN & 0.023 & 0.018 & -0.004 & -1.287 \\
TECH & 1.786 & 1.778 & -0.008 & -0.132 \\
BOD & 5.122 & 5.160 & 0.037 & 0.294 \\
BOC & 4.667 & 4.780 & 0.113 & 0.946 \\
AUCOM & 3.159 & 3.200 & 0.041 & 1.165 \\
BIG4 & 0.453 & 0.459 & 0.006 & -0.168 \\
ROA & 2.616 & 2.472 & -0.144 & 0.447 \\
LOSS & 0.266 & 0.279 & 0.013 & 1.698 \\
FSIZE & 22.018 & 22.196 & $0.179^{*}$ & 1.052 \\
LEV & 0.590 & 0.632 & 0.042 & 1.311 \\
PPE & 20.837 & 21.002 & 0.165 & 0.960 \\
LNLOAN & 19.311 & 19.448 & 0.137 & .
\end{tabular}

Note(s): This table reports the two-sample $t$-test result on 929 firm-years observations. The amount was selected based on sample amount that meet all the PSM requirement that has been selected. This test was done after winsorizing the data for 1 percent and 99 percent. $t$ statistics in parentheses ${ }^{*} p<0.1,{ }^{* * *} p<0.05,{ }^{* * * * *} p<0.01$

Table A4.

2 -sample $t$-test on PSM model 